The oceanic biogeochemistry of nickel and its isotopes: New data from the South Atlantic and the Southern Ocean biogeochemical divide

\author{
Archer, C
}

http://hdl.handle.net/10026.1/15435

10.1016/j.epsl.2020.116118

Earth and Planetary Science Letters

Elsevier BV

All content in PEARL is protected by copyright law. Author manuscripts are made available in accordance with publisher policies. Please cite only the published version using the details provided on the item record or document. In the absence of an open licence (e.g. Creative Commons), permissions for further reuse of content should be sought from the publisher or author. 
Disclaimer: This is a pre-publication version of the following article: Archer, C., Vance, D., Milne, A., and M. Lohan (2020). Readers are recommended to consult the final published version for accuracy and citation at doi.org/10.1016/j.epsl.2020.116118

\title{
The oceanic biogeochemistry of nickel and its isotopes: new data from the South Atlantic and the Southern Ocean biogeochemical divide
}

\author{
Corey Archer1*, Derek Vance', Angela Milne², Maeve C. Lohan³
}

${ }^{1}$ Institute of Geochemistry and Petrology, Department of Earth Sciences, ETH Zürich, Clausiusstrasse 25, 8092 Zürich, Switzerland.

${ }^{2}$ School of Geography, Earth and Environmental Sciences, University of Plymouth, Drake Circus Plymouth, PL4 8AA, UK.

${ }^{3}$ School of Ocean and Earth Sciences, National Oceanography Centre, University of Southampton, Southampton, UK.

*Corresponding author: corey.archer@erdw.ethz.ch; phone +41 446326342. 


\section{Abstract}

Nickel (Ni) is a bio-active metal that is important for a number of enzymes in oceanic phytoplankton. It has received less attention than some other bioactive metals because it is not reduced to extremely low dissolved concentrations in the photic zone. However, there are strong indications in previous studies that this residual pool is not bio-available. Oceanic Ni isotope data are still scarce, but have great potential for understanding this issue, as well as for understanding the Ni mass balance of the oceans now and in the past. Here, we present new concentration and isotope data for the UK GEOTRACES section at $40^{\circ} \mathrm{S}$ in the Atlantic (GA10). Nickel concentration data show typical nutrient-like profiles, slightly modified by variable pre-formed concentrations in sub-surface water masses, e.g. North Atlantic Deep Water. Nickel isotopes, in common with findings in previous studies, are homogeneous beneath $500 \mathrm{~m}$, at about $+1.3 \%$ in $\delta^{60} \mathrm{Ni}$, in samples with Ni concentrations above 3-3.5 nM. The surface South Atlantic, however, have concentrations below $3 \mathrm{nM}$, show significantly heavier values, up to $+1.74 \%$, that are closely anti-correlated with Ni concentrations.

The data for the deep South Atlantic dissolved pool, with a $\delta^{60} \mathrm{Ni}=1.31 \pm 0.12 \%$ (average and 2SD) confirm the homogeneity of the global deep ocean, which previous data demonstrate extends all the way to the surface in the upwelling zone of the Southern Ocean south of the Polar Front. This Ni isotope composition is significantly heavier than known inputs to the oceanic dissolved pool. This mass balance requires an isotopically light sink that may be represented by sedimentary Mn-oxide associated $\mathrm{Ni}$. The magnitude of the isotope fractionation implied by the upper ocean data is not consistent with plausible potential abiotic removal processes. Rather, these data are best explained by biological uptake. However, consideration of the detailed relationships between $\mathrm{Ni}$ concentrations and isotope compositions requires that a substantial portion of the oceanic dissolved $\mathrm{Ni}$ pool is not bio-available. The data are consistent either with a small preference for the light isotope during uptake (about 0.1 $\%$ ) or two distinct pools of dissolved $\mathrm{Ni}$, one bio-available and one strongly bound in organic complexes, with limited isotopic exchange between them. Patterns of co-variation in Ni concentrations and isotopes with the major nutrients point to strong contrasts across the Polar Front of the Southern Ocean, contrasts that exhibit both similarities and differences with those for the major nutrients and other trace metal micronutrients. South of the Polar Front, Ni is taken up in modest amounts by diatoms, without isotope fractionation. North of the Polar Front the data are most consistent with cyanobacteria as the dominant control on Ni uptake, with significant isotope variation. 


\section{Introduction}

Many transition metals have important roles in ocean biogeochemistry, played out through photosynthetic carbon fixation by marine phytoplankton and the metabolic processes that go with it (Morel and Price, 2003). Nickel (Ni) is one such bioactive transition metal and, in common with others, shows a nutrient-like profile in the modern ocean (Sclater et al., 1976; Bruland, 1980; Mackey et al., 2002). Specifically, dissolved Ni is depleted in the photic zone, suggestive of biological uptake, and shows concentration maxima at depth, consistent with regeneration. In areas like the North Pacific (Fig. 1), away from complexities associated with the variable pre-formed nutrient contents of sub-surface water masses, depth profiles of dissolved $\mathrm{Ni}$ are similar to those of phosphate and nitrate in the upper ocean (Fig. 1), implying a significant reservoir associated with phytoplankton organic matter. At depth there is a closer relationship with dissolved silicate (Sclater et al., 1976; Bruland, 1980).

Nickel is known to have specific and key metabolic roles in eukaryotic and prokaryotic organisms (e.g. Ragsdale, 2009). In the modern oxygenated ocean, Ni plays an important role in the metalloenzyme urease, utilised by phytoplankton in the hydrolysis of urea to yield ammonia (e.g. Ragsdale, 2009). Dupont et al. (2010) suggest that urea may supply up to $50 \%$ of the fixed nitrogen required for oceanic primary production. In cultures of diatoms and cyanobacteria grown on urea as the sole source of nitrogen (Price and Morel, 1991; Dupont et al., 2008), and in natural assemblages (Dupont et al., 2010), phytoplankton growth has been shown to be limited by the availability of $\mathrm{Ni}$, suggesting that $\mathrm{Ni}-\mathrm{N}$ colimitation of phytoplankton may be relevant to many oceanic settings (Price and Morel, 1991; Saito et al., 2008; Dupont et al., 2010). Furthermore, culture studies have shown that some strains of cyanobacteria, even when grown on nitrate or ammonia, can be growth limited by the availability of $\mathrm{Ni}$ (Dupont et al., 2008). This latter study highlights another key Nidependent process in the marine realm: the breakdown of the toxic superoxide by superoxide dismutase (SOD) enzyme, and that the Ni containing isoform, Ni-SOD, is required by at least some strains of cyanobacteria (Dupont et al., 2008; Ragsdale, 2009). Scarce quantitative information on the trace metal quotas of natural phytoplankton (Twining and Baines, 2013, see their Table 2) also suggest that the highest cellular Ni/P ratios occur in nitrogen-fixing cyanobacteria. On the other hand, Twining et al. (2012) emphasise the role of diatom opal in controlling oceanic depth profiles, suggesting that this phase contains about $50 \%$ of diatom cellular $\mathrm{Ni}$ quotas, and that $\mathrm{Ni}: \mathrm{Si}$ ratios in diatom frustules are comparable to those of dissolved depth profiles. 
Whereas many bioactive metals, such as $\mathrm{Fe}, \mathrm{Cd}$, and $\mathrm{Zn}$, are often depleted to near zero concentrations in the photic zone (e.g. Fig. 1), the concentration of open ocean $\mathrm{Ni}$ appears not to decrease below about 1.8 to 2 nM (e.g. Sclater et al., 1976; Bruland, 1980; Mackey et al., 2002). It has been suggested that this apparent non-zero minimum in $\mathrm{Ni}$ concentration represents a pool that is bound by organic ligands, in strong complexes that show much slower rate constants for dissociation than for other metals (e.g. Boiteau et al., 2016), and that may not be available to phytoplankton (Mackey et al., 2002). This inference is supported by incubation experiments in which natural $\mathrm{Ni}$ was found not to equilibrate with ${ }^{63} \mathrm{Ni}$-enriched additions (Dupont et al., 2010). The idea that a large proportion of dissolved oceanic Ni may not be bio-available has been cited to explain the fact that, despite total $\mathrm{Ni}$ concentrations of 3-4 $\mathrm{nM}$ in starting seawater, additions of only $0.75 \mathrm{nM}$ lead to a significant biological response (Dupont et al., 2010).

The first data on the Ni isotopic composition of seawater suggest a homogeneous deep ocean (Cameron and Vance, 2014; Takano et al., 2017). In common with many other metal isotope systems, dissolved $\mathrm{Ni}$ in the deep ocean is also isotopically heavier than both the bulk Earth, and known inputs to the oceans (Cameron and Vance, 2014; Vance et al., 2016). Iron-manganese crusts are one manifestation of an important sink for $\mathrm{Ni}$ in the oceans - adsorption to iron-manganese (Fe-Mn) oxides - and record a wide range of Ni isotope composition but with an average that is slightly heavier than the oceanic dissolved pool (at around +16\%; (Gall et al., 2013; Gueguen et al., 2016)), and much heavier than the riverine input (Cameron and Vance, 2014). In contrast, laboratory experiments have demonstrated that lighter Ni isotopes preferentially sorb to Fe-Mn oxide surfaces (Wasylenki et al., 2015; Gueguen et al., 2018), suggesting that this process is not so straightforward in nature. Recent studies of the Ni output to sediments in sulphidic basins (Vance et. al., 2016) and to organicrich sediments at upwelling margins (Ciscato et al., 2018) have uncovered significantly to slightly light sinks of $\mathrm{Ni}$ from the oceanic dissolved pool. Overall, these data suggest that the oceanic budget of $\mathrm{Ni}$ and its isotopes is not balanced, and that an additional large light sink is needed, a situation analogous to that for Zn (e.g. Little et al., 2014). Recent data have shown that in South Pacific surface waters, the Ni isotope pool is fractionated to heavier values versus the deep ocean (Takano et al., 2017), consistent with the idea that phytoplankton preferentially incorporate lighter $\mathrm{Ni}$ isotopes.

Here, we present new $\mathrm{Ni}$ and $\mathrm{Ni}$ isotope data from a transect along $40^{\circ} \mathrm{S}$ in the south Atlantic Ocean, from samples collected as part of the UK GEOTRACES transect GA10, sub- 
divided into cruises D357 and JC068 (Fig. 2). We use these and published data to understand the processes controlling the biogeochemical cycling of $\mathrm{Ni}$ in the oceans in general, as well as the mass balance problem.

\section{Sampling and analytical methodology}

All work was carried out under trace metal clean conditions, using acid cleaned PFA labware except where stated. Ultra-pure 18.2 M $\Omega . c m$ water (MilliQ, Millipore) was used throughout, and acids and reagents were either purchased as ultrapure, double distilled or cleaned via ionexchange methods.

\subsection{Sampling methods}

Seawater was collected for $\mathrm{Ni}$ isotope analysis from six superstations, following GEOTRACES protocols, during two cruises along latitude $40^{\circ} \mathrm{S}$ as part of the UK GEOTRACES GA10 transect (Table 1; Fig. 2; Browning et al., 2014b; Wyatt et al., 2014; Little et al., 2018). Briefly, samples were collected using twenty-four $10 \mathrm{~L}$ Teflon-coated Niskin (Ocean Test Equipment, OTE) samplers mounted on a titanium CTD frame deployed on a plasma rope. Surface samples were collected by pumping water from $\sim 3 \mathrm{~m}$ depth, portside, directly into the on-board trace metal clean laboratory using a teflon diaphragm pump connected by acid-washed braided PVC tubing to a towed "fish" sampling device. Once on board, all samples were filtered through $0.2 \mu \mathrm{m}$ AcroPak Supor polyethersulfone membrane filter capsules (Pall) into acid-cleaned 1 or $4 \mathrm{~L}$ low density polyethylene (LDPE) bottles and acidified to $\mathrm{pH} 1.7$ by addition of $12 \mathrm{M}$ hydrochloric acid (HCl, UpA, Romil).

\subsection{Dissolved Ni and Ni isotope analysis}

Trace metals were pre-concentrated from $0.2-4 \mathrm{~L}$ seawater samples using an ethylenediaminetriacetic acid chelating resin, sold commercially as Nobias PA- (Hitachi High Technologies; Sohrin et al., 2008). Nobias resin was held in PFA Teflon cartridges, with a resin bed of $7 \mathrm{~mm}$ I.D. by $25 \mathrm{~mm}$ length. Samples were loaded onto the columns using a peristaltic pump, and trace metals were eluted using nitrogen gas pressure and a flow-through procedure modified from Takano et al. (2013) as described in Vance et al. (2016). Prior to 
pre-concentration, samples acidified to $\mathrm{pH} 2$ were equilibrated for $24 \mathrm{~h}$ with ${ }^{61} \mathrm{Ni}-{ }^{62} \mathrm{Ni}$ double spike. Samples were then adjusted to $\mathrm{pH} 5 \pm 0.3$ using an ammonium acetate buffer, made up to a final acetic acid concentration of $30 \mathrm{mM}$, before loading onto the column. Matrix cations, principally $\mathrm{Na}, \mathrm{Mg}$ and $\mathrm{Ca}$, were eluted with $100 \mathrm{ml}$ of $30 \mathrm{mM}$ ammonium acetate buffer, followed by the elution of the trace metal budget using $20 \mathrm{ml} 1 \mathrm{M} \mathrm{HNO}_{3}$. The trace metal eluate was then evaporated to dryness and re-dissolved in $7 \mathrm{M} \mathrm{HCl}$ for subsequent $\mathrm{Ni}$ purification by ion-exchange column chromatography.

The Ni fraction of the trace metal pre-concentrate was purified, from other trace metals and residual major cations, using a multi-step procedure modified from previously described protocols (Cameron et al., 2009; Cameron and Vance, 2014; Vance et al., 2016; Wang et al., 2019). The first step involved passing the trace metal mixture through an anion exchange resin, AG MP-1M (Bio-Rad) to isolate Ni from other transition metals. The Ni fraction was then further purified using a miniaturised, gravity driven, version of the Nobias pre-concentration column (Wang et al., 2019). This column replaced the DMG (dimethylglyoxime) column previously used by this lab for the purification of $\mathrm{Ni}$ (Cameron et al., 2009; Cameron and Vance, 2014), and was employed specifically to remove any residual $\mathrm{Na}, \mathrm{Mg}$ or Ca remaining from the initial pre-concentration. The advantage of using this method is a significantly lower Ni blank (see below). Though it does not separate Ni from any $\mathrm{Al}$ that may be in the sample, the typically low dissolved $\mathrm{Al}$ concentrations in seawater in this region were not found to have any effect on $\mathrm{Ni}$ isotope analysis. The $\mathrm{Ni}$ fraction was then finally passed through a second, small, anion column to remove any residual $\mathrm{Fe}$ or $\mathrm{Zn}$ (Cameron et al., 2009; Cameron and Vance, 2014; Wang et al., 2019). The total blank for this procedure was less than $0.5 \mathrm{ng}$, is negligible, and is not corrected for here.

The Ni fraction was analysed for its isotopic composition using a Thermo Scientific Neptune Plus MC-ICP-MS at ETH Zürich in low-resolution mode. Samples were introduced in a $2 \%(\mathrm{v} / \mathrm{v})(\sim 0.3 \mathrm{M}) \mathrm{HNO}_{3}$ solution via a Savillex C-Flow PFA nebuliser $\left(50 \mu \mathrm{min}^{-1}\right)$ attached to a Teledyne-Cetac Aridus II desolvator. Typically, approximately $30 \mathrm{ng}$ of Ni was consumed per analysis. ${ }^{56} \mathrm{Fe}$ was measured as a monitor of a potential interference from ${ }^{58} \mathrm{Fe}$ on ${ }^{58} \mathrm{Ni}$. In all cases, these measured interferences were negligible. Instrumental mass fractionation was corrected for using the Ni double spike, using methods detailed previously (Cameron et al., 2009; Cameron and Vance, 2014), and dissolved Ni concentrations were calculated by isotope dilution. All Ni isotopic compositions are given in standard delta notation as follows relative to the NIST SRM986 standard: 


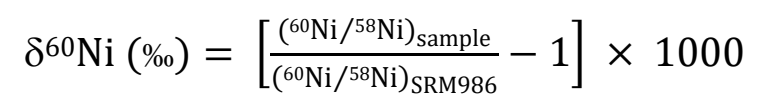

Long-term reproducibility of $\mathrm{Ni}$ isotopic analyses in our lab is $\pm 0.07 \%$, assessed over the course of this and parallel studies, through repeat measurements of primary NIST standards as well as a secondary standard Ni (USGS Fe-Mn nodule, Nod-A1, digested and passed through the Ni column chemistry). These latter give $\delta^{60} \mathrm{Ni}_{\text {NIST SRM986 }}=+1.04 \pm 0.07 \%$ ( 2 s.d., n=175 over 4 years), in agreement with previously published results (Gueguen et al., 2013). Internal errors obtained from the mass spectrometric analysis and propagated through the double spike algebra were virtually always substantially lower than long-term reproducibility, and are given in Table 1. The uncertainties shown on all figures are the long-term reproducibility $( \pm 0.07)$, unless the internal uncertainty is larger, in which case the latter is shown.

The first Ni isotope data for seawater in Cameron and Vance (2014) were obtained using pre-concentration with Al-hydroxide. Data for the Atlantic sector of the Southern Ocean obtained this way are slightly heavier, just outside of analytical uncertainty, versus more recent data for the Southern Ocean and the global deep ocean obtained using the more robust methodology used here and in Takano et al. (2017) and Wang et al. (2019). Data for the Southern Ocean in Cameron and Vance (2014) are important later in comparing Ni isotope data north and south of the Southern Ocean Polar Front. Thus, these samples have been reanalysed, where possible, and the new data are used here. For samples where this was not possible these original data are plotted with a small correction, based on the data from the reanalysed samples, to account for this systematic offset. Details of this approach, including an intercomparison between the old and new data, are given in the supplementary information.

\section{Results}

All data for dissolved Ni concentrations and its isotopic composition, as well as major nutrient data, are presented in Table 1 and Figures 3 and 4. At all 6 of the stations sampled, Ni concentrations are constant at about $7 \mathrm{nM}$ beneath $3000 \mathrm{~m}$ (Fig. 4). The South Atlantic is a basin where mixing of different water masses with different pre-formed nutrient contents is particularly clear (Fig. 3). This feature is also seen for Ni concentrations (Fig. 4), with depth profiles showing reversals in Ni concentrations of North Atlantic Deep Water (NADW), at $2000 \mathrm{~m}$ and $3000 \mathrm{~m}$ depth, deviating about $1 \mathrm{nM}$ below those above and below. Otherwise, 
dissolved Ni concentration profiles observed in the South Atlantic are similar to previously observed "nutrient-type" profiles for $\mathrm{Ni}$ in other areas of the global ocean (e.g. Fig. 1; Sclater et al., 1976; Bruland, 1980; Mackey et al., 2002; Takano et al., 2017). Moreover, above depths of $500 \mathrm{~m}$ concentrations decrease to a minimum value of $\sim 2 \mathrm{nM}$ at the surface, also consistent with these previous studies.

$\mathrm{Ni}$ isotope compositions are also homogenous in the deep ocean, with an average $\delta^{60} \mathrm{Ni}$ value of $+1.31 \pm 0.12 \%$ below $500 \mathrm{~m}$ (Fig. 4), including across the NADW interval, in broad agreement with previous observations (Cameron and Vance, 2014; Takano et al., 2017). Above $500 \mathrm{~m}$, as Ni concentrations decrease towards the surface, the isotope composition becomes heavier, with $\delta^{60} \mathrm{Ni}$ increasing to values as high as $+1.74 \%$. This finding is similar to recent observations in the sub-tropical South Pacific (Takano et al., 2017; Wang et al., 2019), but stands in contrast to data for the Southern Ocean, which are virtually isotopically homogeneous throughout the entire depth range (Cameron and Vance, 2014; Wang et al., 2019). These latter profiles often show no significant surface depletion in $\mathrm{Ni}$ relative to deep concentrations. On the other hand, a North Pacific profile in Cameron and Vance (2014) shows a factor of two depletion at the surface but no Ni isotope shift, versus the significant Ni shift associated with a factor of 2.5-3 drop in concentrations seen here and in Takano et al. (2017). Thus, surface depletion on its own, is not always associated with heavy $\mathrm{Ni}$ isotopes. Rather, taking all the available data as a whole, the key characteristic that is associated with heavy $\mathrm{Ni}$ isotopes in the surface ocean seems to be $\mathrm{Ni}$ concentrations beneath a threshold level: the North Pacific profile in Cameron and Vance (2014) has a minimum concentration of $5.54 \mathrm{nM}$, whereas heavy surface Ni isotopes here and in Takano et al. (2017) are? always associated with Ni concentrations below about 3-3.5 nM (Table 1). A more relevant expression of the homogeneity of the South Atlantic dataset may thus be the fact that all samples with $\mathrm{Ni}$ concentration $\geq 3.5 \mathrm{nM}$ have a $\delta^{60} \mathrm{Ni}$ value of $+1.33 \pm 0.13 \%$. 


\section{Discussion}

The data presented here adds significantly to the emerging picture of Ni isotope systematics in the oceanic realm. This study presents only the fourth open ocean Ni isotope dataset (this study; Cameron and Vance, 2014; Takano et al., 2017; Wang et al., 2019), the fifth oceanic dataset in total including one from the Black Sea (Vance et al., 2016). The following discussion starts with the deep ocean, focussing on the comparisons and contrasts between the data presented here for the South Atlantic and published data for other parts of the oxygenated global ocean. We then move on to consider the processes that could lead to the observed variability in the upper ocean, focussing on biological uptake and associated isotope fractionation. Finally, we consider the new data in terms of the biogeochemical cycling of $\mathrm{Ni}$ and its isotopes in the ocean, including the overall oceanic mass balance.

\subsection{Ni and its isotopes in the deep South Atlantic versus the global open ocean}

The Ni isotope homogeneity of the deep oceans, or of samples with Ni concentrations above $3.5 \mathrm{nM}$, was noted in the results section. For two of the profiles studied here (Stations 6,18 ), samples in the $\geq 3.5 \mathrm{nM}$ category extend through the entire depth profile and into the photic zone, while stations 12 and 21 stand out in particular as having lower upper ocean concentrations and more variable isotope values. Furthermore, though the core of NADW in the South Atlantic is characterised by lower Ni concentrations than water above and below, it is no different in Ni isotopes (Figs. 3, 4). It is again noteworthy that Ni concentrations in NADW, though lower than water masses either side, remain significantly higher than 3-3.5 $\mathrm{nM}$. The deep ocean isotopic homogeneity implied by these and published data is not surprising given estimates of the residence time of Ni relative to the mixing time of the ocean (Sclater et al., 1976; Cameron and Vance, 2014), and holds features in common with an emerging picture of trace metal isotope distribution in the deep ocean (e.g. Conway and John, 2014; Zhao et al., 2014; Little et al., 2018).

The South Atlantic data also confirm another important and previously-recognised feature of oceanic $\mathrm{Ni}$ isotopes (Cameron and Vance, 2014): the dissolved pool is significantly heavier than the known inputs. Rivers measured thus far suggest a global discharge- and concentration-weighted $\delta^{60} \mathrm{Ni}$ around $+0.8 \%$ (Cameron and Vance, 2014), with limited data for estuarine mixing suggesting that mixing between freshwater and the oceanic end-member is close to conservative (Boyle et al., 1982; Edmond et al., 1985). Though the isotope 
composition of the small continent-derived aerosol flux has not yet been measured, it is likely to be isotopically similar to the upper continental crust at $\pm 0.14 \pm 0.23 \%$ (Cameron et al., 2009; Ciscato et al., 2018). Ciscato et al. (2018) present arguments based on GEOTRACES section data to suggest that hydrothermal systems are not a significant source of Ni to the oceanic dissolved pool. Putting all of this together, if the ocean is to be in isotopic steadystate, an additional heavy source or a large, light sink is required. We return to the mass balance issues at the end of this paper.

\subsection{Isotopically heavy $\mathrm{Ni}$ in the surface ocean}

In contrast to the deep ocean, and the data so far available from the surface Southern Ocean (Wang et al., 2019), there is a clear shift towards heavier isotope compositions in the South Atlantic as concentrations decrease towards the surface (Fig. 4). Here, $\delta^{60} \mathrm{Ni}$ values increase to $+1.74 \%$, and this isotopic shift is associated with a concentration decrease from $\sim 7 \mathrm{nM}$ to $<2.5 \mathrm{nM}$. A near identical pattern has been reported from the South Pacific (Takano et al., 2017). In assessing the cause of this effect, we compare the fractionation factor suggested by the data themselves with those for specific potential processes. Data for the South Atlantic from this study and South Pacific from Takano et al. (2017) are plotted in Fig. 5. Clearly, the data from the upper ocean from both locations are consistent with removal of Ni from the dissolved to a particulate pool (in a simple closed-system Rayleigh fractionation model) with an alpha $(\alpha)$ value of $0.99965\left({ }^{60} \mathrm{Ni} /{ }^{58} \mathrm{Ni}_{\text {particulate }} /{ }^{60} \mathrm{Ni} /{ }^{58} \mathrm{Ni}_{\text {dissolved }}\right)$ or a $\Delta^{60} \mathrm{Ni}_{\text {particulate-aqueous }}=-0.35 \%$. We argue in section 4.4 that this may be a maximum value for the isotopic effect associated with Ni removal from solution, but this result is sufficient to allow us to explore the processes responsible for Ni removal from solution in these two locations, which we do below.

Removal of Ni by scavenging to particulate matter represents one possible process, one that has been suggested to operate for other transition metals, e.g., $\mathrm{Cu}$ (e.g. Little et al., 2018) and Zn (e.g. Conway and John, 2014). Manganese redox cycling across the Black Sea chemocline is clearly associated with the preferential sorption to Mn oxide of the light isotopes of $\mathrm{Ni}$ (Vance et al., 2016), with a $\Delta^{60} \mathrm{Ni}_{\text {sorbed-aqueous }}=-4 \%(\alpha=0.996)$. This fractionation, though large for metal isotopes, is identical to that found for sorption of Ni to Mn oxides in experiments that have, thus far, been reported only in abstract form (Wasylenki et al., 2014 AGU Fall Meeting Abstracts). Though a similar process could, in principle, 
explain the heavy values in the upper ocean in the South Atlantic and South Pacific, it is clearly ruled out by the much more subtle isotope effect implied by the data in Fig. 5.

It has also been hypothesised that transition metals could be removed from the water column as sulphides that precipitate in reducing microenvironments on sinking particles, particularly in oxygen deficient zones (ODZ) of the ocean (e.g. Janssen and Cullen, 2015). Again, the Black Sea data provides a clue to the size of the isotopic effect expected. Ni concentration and speciation calculations (Landing and Lewis, 1991) for the deep sulphidic Black Sea suggest equilibrium between soluble Ni and particle reactive sulphide species. The coupled variability in $\mathrm{Ni}$ concentrations and isotopes implies preferential removal of the light isotope to sulphide with $\alpha \sim 0.9993$, consistent with a $\Delta^{60} \mathrm{Ni}_{\mathrm{Ni}(\mathrm{HS})+-\mathrm{Ni} 2+}$ of approximately 0.66 from theoretical calculations (Fujii et al., 2011). Though this process occurs in restricted environments such as the Black Sea, and might be possible in oxygen deficient zones of the open ocean, it is extremely unlikely to be important in the well oxygenated open-ocean, such as the South Atlantic or South Pacific. It is also ruled out by the fractionation factor associated with the data in Fig. 5.

Finally, the data from both the South Atlantic and the South Pacific Oceans are also clearly consistent with preferential photic zone uptake of light $\mathrm{Ni}$ isotopes into phytoplankton cells. No culture data are available to assess the magnitude of any isotope fractionation associated with biological uptake. But the direction and magnitude of the fractionation implied by the data in Fig. 5 - i.e. a small preference for uptake of the light isotope - are similar to those obtained from culture experiments for other transition metal micronutrients across a range of different species (e.g. Lacan et al., 2006; John et al., 2007; Köbberich and Vance, 2019). The magnitude of the fractionation implied by Fig. 5 is also consistent with that suggested for biological uptake by the $\mathrm{Ni}$ abundance and isotope systematics of organic matter in sediments of the Peru upwelling region (Ciscato et al., 2018).

In the next section we present arguments that not only confirm the importance of biological uptake for photic zone $\mathrm{Ni}$ and its isotopes, but also highlight a major biogeochemical contrast between the Southern Ocean, south of the Polar Front (Cameron and Vance, 2014; Wang et al., 2019), versus the low latitude ocean to the north (Takano et al., 2017; this study).

\subsection{Ni-nutrient relationships: ecological controls on Ni isotope fraction}


Previous work on the importance of Ni to marine phytoplankton has highlighted the importance of two main groups of organisms. First, Twining et al. $(2004,2012)$ found diatoms to have significantly higher Ni/P ratios than flagellated and pico-eukaryotes $(0.73-$ 1.15 versus $0.07-0.49 \mathrm{mmol} / \mathrm{mol}$ ). Diatom incubation experiments (Twining et al., 2012) further suggested $\mathrm{Ni} / \mathrm{P}$ uptake ratios of around $0.52 \pm 0.10 \mathrm{mmol} / \mathrm{mol}$, and significant $\mathrm{Ni}$ contents in diatom opal (with $\mathrm{Ni} / \mathrm{Si}$ uptake ratios into the opal of $28 \pm 13 \mu \mathrm{mol} / \mathrm{mol}$ ). However, these authors also note reports of even higher $\mathrm{Ni} / \mathrm{P}$ ratios in cyanobacteria, and that upper water column $\mathrm{Ni} / \mathrm{P}$ ratios are twice as high as needed for internal diatom biomass (Twining et al., 2012). These findings are consistent with very high $\mathrm{Ni} / \mathrm{P}$ uptake ratios for cyanobacteria in both culturing and incubation experiments (Dupont et al., 2008; 2010). In addition, Dupont et al. (2008) showed that two strains of marine Synechococcus became Ni-N limited when grown on urea, while one of the two strains studied exhibited an obligate requirement for $\mathrm{Ni}$ regardless of nitrogen source, suggesting a requirement for Ni in Ni-SOD (Dupont et al., 2008). Furthermore, bottle-based fertilization studies consistently promoted growth of naturally-occurring cyanobacteria and pico-eukaryotes in Gulf of California surface waters in response to additions of $\mathrm{Ni}$ only, urea only, or $\mathrm{Ni}+$ urea, suggestive of independent $\mathrm{Ni}-\mathrm{N}$ colimitation and Ni-limitation related to both urease and Ni-SOD activity (Dupont et al., 2010).

$\mathrm{Ni}$ concentration and isotope data, in combination with data for the major nutrients (Fig. 6), have important implications for these questions concerning the oceanic biogeochemistry of $\mathrm{Ni}$, and also highlight a profound difference between $\mathrm{Si}-\mathrm{P}-\mathrm{N}-\mathrm{Ni}-\delta^{60} \mathrm{Ni}$ systematics to the south and north of the Polar Front that echoes those documented for other nutrients (Sarmiento et al., 2004; Vance et al., 2017). For example, all the data from the region of the Polar Front and to the south (Cameron and Vance, 2014; Wang et al., 2019) exhibit slopes in Ni-Si and Ni-P space that are consistent with $\mathrm{Ni} / \mathrm{Si}$ and $\mathrm{Ni} / \mathrm{P}$ uptake/remineralisation ratios of around $10 \mu \mathrm{mol} / \mathrm{mol}$ and about $0.77 \mathrm{mmol} / \mathrm{mol}$, respectively. These ratios are close to those found by Twining et al. (2012) for diatom cells, of $28 \pm 13 \mu \mathrm{mol} / \mathrm{mol}$ and $0.52 \pm 0.10 \mathrm{mmol} / \mathrm{mol}$. Ni-Si co-variation in the South Atlantic and South Pacific deep oceans suggest a very similar Ni/Si ratio of around $18 \mu \mathrm{mol} / \mathrm{mol}$. These findings, together, are consistent with: (1) the fact that both macronutrient and metal micronutrient uptake in the surface Southern Ocean south of the Polar Front is dominated by diatoms (e.g. Browning et al., 2014a) and (2) the fact that deep waters of the South Atlantic 
and South Pacific share a source in deep water advected out of the Southern Ocean (e.g. Sarmiento et al., 2007).

In the Ni-Si plot (Fig. 6A), the array defined by data at or south of the Polar Front extends all the way to zero silica. Data for the South Atlantic and South Pacific show very different behaviour, departing from this array at Si concentrations beneath about $20 \mu \mathrm{M}$, corresponding to waters in the upper $500-600 \mathrm{~m}$ in both cases. Indeed, the slope of this steep array is consistent with a Ni/Si uptake ratio of $>130 \mu \mathrm{mol} / \mathrm{mol}$, much higher than either those previously obtained for diatoms (Twining et al., 2004; 2012) or for surface water to the south of the Polar Front, and suggesting that organisms with very different Ni to major nutrient uptake ratios control Ni behaviour north of the Polar Front. The Ni/P ratio for the entire dataset from the South Atlantic and South Pacific is $>2 \mathrm{mmol} / \mathrm{mol}$, again a factor of $2-4$ higher than those cited above for diatoms or for surface water in the Southern Ocean.

Metal micronutrient to major nutrient ratios have proved an important addition to those of the major nutrients themselves in elucidating the divide marked by the Southern Ocean's Polar Front (e.g. Vance et al., 2017). This divide in the behaviour of the metal micronutrients extends to their stable isotope systems, but in ways that differ significantly from metal to metal. Thus, though $\mathrm{Zn}$ shows very strong co-variation with $\mathrm{Si}$ in surface waters of the Southern Ocean in response to rapid uptake of both by diatoms, this rapid uptake involves such a tiny isotope fractionation that these surface waters exhibit barely significant variations in $\mathrm{Zn}$ isotope ratios despite drawdown of $>95 \%$ of the $\mathrm{Zn}$ upwelled to the surface there (Zhao et al., 2014; Wang et al., 2019). Cadmium is also rapidly taken up from the surface waters of the Southern Ocean, though the peak drawdown occurs slightly to the north of that for $\mathrm{Zn}$ (Abouchami et al., 2011; Zhao et al., 2014). In contrast to Zn, however, the light isotopes of $\mathrm{Cd}$ are preferentially taken up (Abouchami et al., 2011). As a result, the surface water that forms the sources of upper ocean water masses advected out of the Southern Ocean are heavy for Cd isotopes whereas any further biological cycling in the low latitude oceans superimposes only very limited further variability (Abouchami et al., 2011; Xue et al., 2013; Xie et al., 2017; Sieber et al., 2019). Intriguingly, the isotopes of Ni also exhibit this switch in behaviour across the Polar Front, but in a pattern that is precisely the opposite of that for $\mathrm{Cd}$. The plot of $\mathrm{Si}$ versus $\delta^{60} \mathrm{Ni}$ in Fig. $6 \mathrm{~B}$ shows that there is virtually no variation in the isotope composition of $\mathrm{Ni}$ in waters with Si concentrations $>10 \mu \mathrm{M}$. In contrast, nearly all upper ocean waters in the South Atlantic at $40^{\circ} \mathrm{S}$ and in the South Pacific 
at $30^{\circ} \mathrm{S}$ have elevated $\delta^{60} \mathrm{Ni}$ (Fig. 6), suggesting that only here is biological uptake associated with an isotope fractionation. This feature is better distinguished in the plots of Ni isotopes against nitrate and phosphate (Figs. 6D, F), where heavy Ni isotope compositions are associated with $\mathrm{NO}_{3}$ and $\mathrm{PO}_{4}$ concentrations below 10 and $0.7 \mu \mathrm{M}$ respectively.

Pigment and flow cytometry data in Browning et al. (2014a, b) suggest that the most significant difference in the ecology of the South Atlantic at $40^{\circ} \mathrm{S}$ versus the Southern Ocean at or south of the Polar Front is the cyanobacteria/diatom ratio. Detailed consideration of the pigment and flow cytometry data (Browning et al., 2014b) provides strong hints that it is the switch from a diatom-dominated ecology to the south of the Polar Front to one where cyanobacteria are much more important to the north that is key. Thus, for example, Station 21 is where the heavy $\mathrm{Ni}$ isotope signature and low Ni concentrations are most clearly seen, centred on 50-100m. This station also exhibits a peak in Prochlorococcus cell numbers, at 40-80m (see Browning et al., 2014b, Fig. 4). The same correspondence between cyanobacterial cell numbers, low Ni concentrations, and heavy $\mathrm{Ni}$ isotopes is seen in the upper $50 \mathrm{~m}$ at Station 12 . On the other hand, for Station 18 only the $5 \mathrm{~m}$ sample is heavier than those beneath, despite a strong peak in Synechococcus cell numbers at 40-60m. However, this was also the site of a prominent eddy, domed nutrient contours, and very high nitrate contents at 50m (see Browning et al., 2014b, Fig. 2). These observations together suggest that it is nitrate-limited cyanobacteria that lead to low Ni concentrations and heavy Ni isotopes, consistent with one of the known biochemical roles of Ni discussed earlier (Dupont et al., 2008; 2010). Finally, stations 3, 6 and 11 are intermediate between Stations 21/12 and Station 18 in both Ni concentration and isotope systematics and cyanaobacterial cell counts.

\subsection{Magnitude of Ni isotope fractionation: how much Ni is bioavailable?}

Figure 5 used data from this study as well as those from the South Pacific (Takano et al., 2017) to provide an estimate of the size of the isotope effect associated with removal of Ni from the upper ocean at these two sites. Section 4.3 argued that this removal process is biological uptake. The equivalent of this model Rayleigh scenario is shown again as the red dashed curve in Fig. 7, this time also considering the deep ocean data, and it is clear that such a model does not fit all the data. The magnitude of the isotope effect is influenced by the degree to which all the $\mathrm{Ni}$ in solution is bio-available versus the size of a potentially inert pool that may not participate in ocean biogeochemistry at all. This is an important 
consideration given the ubiquitous minimum in oceanic dissolved $\mathrm{Ni} \sim 1.8-2 \mathrm{nM}$ (Fig. 4; see also data and discussion in Sclater et al., 1976; Bruland, 1980; Mackey et al., 2002; Takano et al., 2017) that is suggested to be the result of a non-bioavailable pool of Ni strongly bound to organic ligands (Mackey et al., 2002), in complexes that exhibit extremely slow dissociation kinetics (Mackey et al., 2002; Dupont et al., 2010; Boiteau et al., 2016).

If it is indeed the case that this $\mathrm{Ni}$ is unavailable to phytoplankton, and that $2 \mathrm{nM}$ is the lower limit that oceanic $\mathrm{Ni}$ concentrations can descend to, then the observed uptake of $\mathrm{Ni}$ represents a virtual exhaustion of the available Ni pool. This implies that Ni behaviour is even closer to that of other micro- and macronutrients in the oceans, where concentrations are reduced to virtually zero at the surface ocean (Bruland, 1980; Morel and Price, 2003). If, as seems likely, it is the case that there remains a pool of Ni that is unavailable to biology, then the fractionation during uptake to drive the surface to its heavier values would be even smaller than that calculated earlier, and the data can be modelled with a fractionation factor, $\alpha$, of 0.99988 , or a $\Delta^{60} \mathrm{Ni}_{\text {particulate-aqueous }}=-0.12 \%$. (dashed blue line in Fig. 7). Finally, one further scenario is explored in Fig. 7. The likelihood that organic ligands play at least some role in mediating the bioavailable $\mathrm{Ni}$ concentration is, in the extreme case, equivalent to the possibility of two distinct reservoirs of $\mathrm{Ni}$ in the oceans. In this extreme case, without any exchange, it is also possible that phytoplankton will have no access at all to the Ni locked away by in strong complexes. Organic ligands are thought to be ubiquitous in the oceans (e.g. Lohan et al., 2015) so that it is possible that these pools of Ni remain distinct throughout the water column. In this scenario, phytoplankton may consume only the available Ni. The solid grey curve in Fig. 7 shows the results of a model whereby: (a) the total dissolved pool is considered as two distinct reservoirs with only one bio-available and distinct in isotope composition (at $+1.2 \%$ ) from a second (at $+1.7 \%$ ) that is not bio-available; (b) Ni is lost from the bio-available pool to uptake without any isotope fractionation.

The data and model curves in Fig. 7 appear to rule out a scenario whereby the entire dissolved pool of $\mathrm{Ni}$ is bioavailable. Though it is impossible to distinguish between the other two possibilities based on the available data, they both imply Ni uptake by phytoplankton with either a small or no isotopic fractionation, as has also been suggested for $\mathrm{Zn}$ uptake (Zhao et al., 2014; Vance et al., 2016; Köbberich and Vance, 2019; Wang et al., 2019). Moreover, these calculations support the suggestion that the $2 \mathrm{nM}$ lower limit of concentration that is observed globally in the oceans may indeed represent a pool of Ni that is not bioavailable (Mackey et al., 2002; Boiteau et al., 2016). 


\subsection{Implications for the oceanic budget of $\mathrm{Ni}$ and its isotopes}

Our current understanding of the sources and sinks of Ni to the oceans suggest that the isotopic budget of $\mathrm{Ni}$ in the oceans is out of balance, a conclusion that is corroborated by an imbalance in the elemental budget (Cameron and Vance, 2014; Vance et al., 2016; Ciscato et al., 2018). The main riverine input of $\mathrm{Ni}$ to the oceans (at $+0.8 \%$ ) has an isotopic composition that is lighter than seawater (at about +1.3 ). On the other hand, Fe-Mn crusts, often used as a convenient sample type to constrain the dominant output, sorption to iron manganese (Fe-Mn) oxides, have an average $\delta^{60} \mathrm{Ni}$ that is close to or heavier than the deep ocean, though they are rather variable (Gall et al., 2013; Cameron and Vance, 2014; Gueguen et al., 2016). In other words, if the oceans are in steady-state, there is either a missing heavy input, or light sink of Ni. The data from this study, as well as those in Takano et al. (2017), point to one such potential light sink: burial of light $\mathrm{Ni}$, taken up by cells, with organic matter in sediments. However, the preference of cells for the light isotopes is small, lying somewhere between 0 and 0.35 per mil. Organic-rich sediments from the Peru Margin have $\mathrm{Ni}$ isotope compositions that are consistent with this small preference, while also exhibiting $\mathrm{Ni} / \mathrm{C}$ ratios which imply a biological $\mathrm{Ni}$ sink that is too small to be the solution to the oceanic mass balance problem (Ciscato et al., 2018). Sulphidic settings like the Black Sea bury Ni that is very significantly (around 1\%o) lighter than seawater, but this euxinic sink is very small and is also not a solution to the mass balance problem (Vance et al., 2016).

A possible way out of this conundrum is that Fe-Mn crusts do not provide an accurate record of the global burial flux of $\mathrm{Ni}$ and its isotopes via sorption to Fe-Mn oxides. As noted by Cameron and Vance (2014) and Ciscato et al. (2018), the Ni contents of these samples, if applicable to the dispersed Mn oxide phase in ambient oxic marine sediment more generally, would suggest a burial flux of $\mathrm{Ni}$ that is much higher than all the known inputs of $\mathrm{Ni}$ combined. Moreover, as noted above, the isotope composition of $\mathrm{Ni}$ in these samples is too heavy for oceanic mass balance. A key characteristic of Fe-Mn crusts is that they do not undergo diagenetic processes that occur in ambient oxic marine sediments. Recent experimental work (Atkins et al., 2016) has suggested that such diagenetic processes lead to phase transformations whereby the Ni sorbed to the original birnessite is released to the aqueous phase. Even if Fe-Mn crusts record the initial removal flux of $\mathrm{Ni}$, if diagenetic reactions such as these, involving Mn oxides buried in sediment in other settings, release $\mathrm{Ni}$ 
that is lost back to the water column, Fe-Mn crusts would overestimate the ultimate burial flux. Furthermore, Mn oxide in marine sediments have Ni/Mn ratios that are factor 2-3 lower than Fe-Mn crusts, and contain isotopically light Ni, at about -0.3\%o (Little et al., 2018 Goldschmidt Abstracts 1545). Thus, if the global flux of Ni to Mn-rich sediment is represented by these measurements as opposed to those for Fe-Mn crusts the mass balance issue may be solved.

\section{Concluding Remarks}

We have presented full depth profiles for $\mathrm{Ni}$ concentrations and stables isotopes at six stations in the South Atlantic Ocean. The dataset confirms and amplifies some key observations in the still small oceanic $\mathrm{Ni}$ isotope dataset, but also has important novel implications. Overall, deep ocean dissolved Ni isotope compositions are homogenous, with an average $\delta^{60} \mathrm{Ni}$ value of $+1.31 \pm 0.12 \%$. This homogeneity extends to the entire water column of the Southern Ocean south of the Polar Front. However, the upper water column in the low latitude oceans shows significant variability that is consistent with biological cycling. The data for the South Atlantic strongly support previous suggestions that about $2 \mathrm{nM}$ of the oceanic dissolved Ni pool is not bio-available. Nickel isotope data for the oceans, overall, are consistent with either a small isotope fractionation during uptake, or with the existence of two isotopically-distinct pools, only one of which is bio-available. The small preference of cells for the light isotope cannot solve the oceanic isotope imbalance for $\mathrm{Ni}$, again consistent with previous inferences (Ciscato et al., 2018).

Nickel and its isotopes represent another manifestation of the profound contrasts across the Southern Ocean Polar Front, previously recognised for the major nutrients as well as for other transition metals. There are also key and intriguing contrasts emerging between the precise behaviour of different metals. Thus, $\mathrm{Zn}$ and $\mathrm{Cd}$ are strongly taken up south of the Polar Front, by a diatom-dominated phytoplankton ecology (Abouchami et al., 2011; Xue et al., 2013; Zhao et al., 2014; Vance et al., 2017; Wang et al., 2019). Cadmium and its isotopes are strongly fractionated during this Southern Ocean drawdown (Abouchami et al., 2011; Xue et al., 2013), while $\mathrm{Zn}$ isotopes are not (Zhao et al., 2014; Wang et al., 2019). Arguments have been made for little further significant biological impact on $\mathrm{Zn}, \mathrm{Cd}$ and their isotopes in the low latitude oceans (Vance et al., 2017; Xie et al., 2017; Sieber et al., 2019). In contrast, Ni exhibits neither significant uptake nor isotope fractionation south of the Polar Front, 
whereas to the north there is substantial drawdown accompanied by significant isotope fractionation, probably by cyanobacteria. The further elucidation of these similarities and contrasts in the context of the modern ocean and its ancient sediments should lead to important research opportunities in the coming years.

\section{Acknowledgements}

The authors thank the chief scientist Gideon Henderson, and the captains, crews and all of the scientists on both legs of the NERC funded UK-GEOTRACES GA10 section (D357 and JC068), grant \# NE/H0044751 to MCL. We thank Shotaro Takano and Urs Menet for their assistance in the lab. We thank Wafa Abouchami for providing some of the samples used for this work. We are also grateful to Tom Browning for fruitful discussions during the preparation of this manuscript. 


\section{References}

Abouchami, W., Galer, S.J.G., de Baar, H.J.W., Alderkamp, A.C., Middag, R., Laan, P., Feldmann, H., Andreae, M.O., 2011. Modulation of the Southern Ocean cadmium isotope signature by ocean circulation and primary productivity. Earth and Planetary Science Letters 305, 83-91. DOI: https://doi.org/10.1016/j.eps1.2011.02.044.

Atkins, A.L., Shaw, S., Peacock, C.L., 2016. Release of Ni from birnessite during transformation of birnessite to todorokite: Implications for Ni cycling in marine sediments. Geochimica et Cosmochimica Acta 189, 158-183. DOI:

https://doi.org/10.1016/j.gca.2016.06.007.

Boiteau, R.M., Till, C.P., Ruacho, A., Bundy, R.M., Hawco, N.J., McKenna, A.M., Barbeau, K.A., Bruland, K.W., Saito, M.A., Repeta, D.J., 2016. Structural Characterization of Natural Nickel and Copper Binding Ligands along the US GEOTRACES Eastern Pacific Zonal Transect. Frontiers in Marine Science 3. DOI: 10.3389/fmars.2016.00243.

Boyle, E.A., Huested, S.S., Grant, B., 1982. The chemical mass balance of the Amazon Plume - II. Copper, nickel, and cadmium. Deep-Sea Research Part a-Oceanographic Research Papers 29, 1355-1364. DOI: 10.1016/0198-0149(82)90013-9.

Browning, T.J., Bouman, H.A., Henderson, G.M., Mather, T.A., Pyle, D.M., Schlosser, C., Woodward, E.M.S., Moore, C.M., 2014a. Strong responses of Southern Ocean phytoplankton communities to volcanic ash. Geophysical Research Letters 41, 2851-2857. DOI: $10.1002 / 2014 \mathrm{~g} 1059364$.

Browning, T.J., Bouman, H.A., Moore, C.M., Schlosser, C., Tarran, G.A., Woodward, E.M.S., Henderson, G.M., 2014b. Nutrient regimes control phytoplankton ecophysiology in the South Atlantic. Biogeosciences 11, 463-479. DOI: 10.5194/bg-11-463-2014.

Bruland, K.W., 1980. Oceanographic distributions of cadmium, zinc, nickel, and copper in the North Pacific. Earth and Planetary Science Letters 47, 176-198. DOI: http://dx.doi.org/10.1016/0012-821X(80)90035-7.

Cameron, V., Vance, D., 2014. Heavy nickel isotope compositions in rivers and the oceans. Geochimica Et Cosmochimica Acta 128, 195-211. DOI: 10.1016/j.gca.2013.12.007.

Cameron, V., Vance, D., Archer, C., House, C.H., 2009. A biomarker based on the stable isotopes of nickel. Proceedings of the National Academy of Sciences of the United States of America 106, 10944-10948. DOI: 10.1073/pnas.0900726106.

Ciscato, E.R., Bontognali, T.R.R., Vance, D., 2018. Nickel and its isotopes in organic-rich sediments: implications for oceanic budgets and a potential record of ancient seawater. Earth and Planetary Science Letters 494, 239-250. DOI: 10.1016/j.epsl.2018.04.061.

Conway, T.M., John, S.G., 2014. The biogeochemical cycling of zinc and zinc isotopes in the North Atlantic Ocean. Global Biogeochemical Cycles 28, 1111-1128. DOI: $10.1002 / 2014 \mathrm{gb} 004862$. 
Dupont, C.L., Barbeau, K., Palenik, B., 2008. Ni uptake and limitation in marine Synechococcus strains. Applied and Environmental Microbiology 74, 23-31. DOI: 10.1128/aem.01007-07.

Dupont, C.L., Buck, K.N., Palenik, B., Barbeau, K., 2010. Nickel utilization in phytoplankton assemblages from contrasting oceanic regimes. Deep-Sea Research Part I-Oceanographic Research Papers 57, 553-566. DOI: 10.1016/j.dsr.2009.12.014.

Edmond, J.M., Spivack, A., Grant, B.C., Hu, M.H., Chen, Z.X., Chen, S., Zeng, X.S., 1985. Chemical dynamics of the Changjiang estuary. Continental Shelf Research 4, 17-36. DOI: 10.1016/0278-4343(85)90019-6.

Fujii, T., Moynier, F., Dauphas, N., Abe, M., 2011. Theoretical and experimental investigation of nickel isotopic fractionation in species relevant to modern and ancient oceans. Geochimica et Cosmochimica Acta 75, 469-482. DOI:

http://dx.doi.org/10.1016/j.gca.2010.11.003.

Gall, L., Williams, H.M., Siebert, C., Halliday, A.N., Herrington, R.J., Hein, J.R., 2013. Nickel isotopic compositions of ferromanganese crusts and the constancy of deep ocean inputs and continental weathering effects over the Cenozoic. Earth and Planetary Science Letters 375, 148-155. DOI: 10.1016/j.epsl.2013.05.019.

Gueguen, B., Rouxel, O., Ponzevera, E., Bekker, A., Fouquet, Y., 2013. Nickel Isotope Variations in Terrestrial Silicate Rocks and Geological Reference Materials Measured by MC-ICP-MS. Geostandards and Geoanalytical Research 37, 297-317. DOI: 10.1111/j.1751908X.2013.00209.x.

Gueguen, B., Rouxel, O., Rouget, M.L., Bollinger, C., Ponzevera, E., Germain, Y., Fouquet, Y., 2016. Comparative geochemistry of four ferromanganese crusts from the Pacific Ocean and significance for the use of $\mathrm{Ni}$ isotopes as paleoceanographic tracers. Geochimica $\mathrm{Et}$ Cosmochimica Acta 189, 214-235. DOI: 10.1016/j.gca.2016.06.005.

Gueguen, B., Sorensen, J.V., Lalonde, S.V., Pena, J., Toner, B.M., Rouxel, O., 2018. Variable Ni isotope fractionation between Fe-oxyhydroxides and implications for the use of $\mathrm{Ni}$ isotopes as geochemical tracers. Chemical Geology 481, 38-52. DOI: 10.1016/j.chemgeo.2018.01.023.

Janssen, D.J., Cullen, J.T., 2015. Decoupling of zinc and silicic acid in the subarctic northeast Pacific interior. Marine Chemistry 177, 124-133. DOI:

https://doi.org/10.1016/j.marchem.2015.03.014.

John, S.G., Geis, R.W., Saito, M.A., Boyle, E.A., 2007. Zinc isotope fractionation during high-affinity and low-affinity zinc transport by the marine diatom Thalassiosira oceanica. Limnology and Oceanography 52, 2710-2714. DOI: 10.4319/lo.2007.52.6.2710.

Köbberich, M., Vance, D., 2019. Zn isotope fractionation during uptake into marine phytoplankton: Implications for oceanic zinc isotopes. Chemical Geology. DOI: https://doi.org/10.1016/j.chemgeo.2019.04.004.

Lacan, F., Francois, R., Ji, Y., Sherrell, R.M., 2006. Cadmium isotopic composition in the ocean. Geochimica et Cosmochimica Acta 70, 5104-5118. DOI:

https://doi.org/10.1016/j.gca.2006.07.036. 
Landing, W.M., Lewis, B.L., 1991. Thermodynamic modeling of trace metal speciation in the Black Sea. Springer Netherlands, Dordrecht

Little, S.H., Archer, C., Milne, A., Schlosser, C., Achterberg, E.P., Lohan, M.C., Vance, D., 2018. Paired dissolved and particulate phase $\mathrm{Cu}$ isotope distributions in the South Atlantic. Chemical Geology 502, 29-43. DOI: https://doi.org/10.1016/j.chemgeo.2018.07.022.

Little, S.H., Vance, D., Walker-Brown, C., Landing, W.M., 2014. The oceanic mass balance of copper and zinc isotopes, investigated by analysis of their inputs, and outputs to ferromanganese oxide sediments. Geochimica et Cosmochimica Acta 125, 673-693. DOI: 10.1016/j.gca.2013.07.046.

Lohan, M.C., Buck, K.N., Sander, S.G., 2015. Organic ligands - A key control on trace metal biogeochemistry in the oceans. Marine Chemistry 173, 1-2. DOI:

10.1016/j.marchem.2015.03.017.

Mackey, D.J., O'Sullivan, J.E., Watson, R.J., Dal Pont, G., 2002. Trace metals in the Western Pacific: temporal and spatial variability in the concentrations of $\mathrm{Cd}, \mathrm{Cu}, \mathrm{Mn}$ and Ni. DeepSea Research Part I-Oceanographic Research Papers 49, 2241-2259. DOI: 10.1016/s09670637(02)00124-3.

Morel, F.M.M., Price, N.M., 2003. The biogeochemical cycles of trace metals in the oceans. Science 300, 944-947. DOI: 10.1126/science.1083545.

Price, N.M., Morel, F.M.M., 1991. Colimitation of phytoplankton growth by nickel and nitrogen. Limnology and Oceanography 36, 1071-1077. DOI: 10.4319/lo.1991.36.6.1071.

Ragsdale, S.W., 2009. Nickel-based Enzyme Systems. Journal of Biological Chemistry 284, 18571-18575. DOI: 10.1074/jbc.R900020200.

Saito, M.A., Goepfert, T.J., Ritt, J.T., 2008. Some thoughts on the concept of colimitation: Three definitions and the importance of bioavailability. Limnology and Oceanography 53, 276-290. DOI: 10.4319/lo.2008.53.1.0276.

Sarmiento, J.L., Gruber, N., Brzezinski, M.A., Dunne, J.P., 2004. High-latitude controls of thermocline nutrients and low latitude biological productivity. Nature 427, 56-60. DOI: 10.1038/nature02127.

Sarmiento, J.L., Simeon, J., Gnanadesikan, A., Gruber, N., Key, R.M., Schlitzer, R., 2007. Deep ocean biogeochemistry of silicic acid and nitrate. Global Biogeochemical Cycles 21. DOI: $10.1029 / 2006 \mathrm{gb} 002720$.

Schlitzer, R., Anderson, R.F., Dodas, E.M., Lohan, M., Geibere, W., Tagliabue, A., Bowie, A., Jeandel, C., Maldonado, M.T., Landing, W.M., Cockwell, D., Abadie, C., Abouchami, W., Achterberg, E.P., Agather, A., Aguliar-Islas, A., van Aken, H.M., Andersen, M., Archer, C., Auro, M., de Baar, H.J., Baars, O., Baker, A.R., Bakker, K., Basak, C., Baskaran, M., Bates, N.R., Bauch, D., van Beek, P., Behrens, M.K., Black, E., Bluhm, K., Bopp, L., Bouman, H., Bowman, K., Bown, J., Boyd, P., Boye, M., Boyle, E.A., Branellec, P., Bridgestock, L., Brissebrat, G., Browning, T., Bruland, K.W., Brumsack, H.J., Brzezinski, M., Buck, C.S., Buck, K.N., Buesseler, K., Bull, A., Butler, E., Cai, P., Mor, P.C., Cardinal, D., Carlson, C., Carrasco, G., Casacuberta, N., Casciotti, K.L., Castrillejo, M., Chamizo, E., Chance, R., Charette, M.A., Chaves, J.E., Cheng, H., Chever, F., Christl, M., Church, T.M., 
Closset, I., Colman, A., Conway, T.M., Cossa, D., Croot, P., Cullen, J.T., Cutter, G.A., Daniels, C., Dehairs, F., Deng, F.F., Dieu, H.T., Duggan, B., Dulaquais, G., Dumousseaud, C., Echegoyen-Sanz, Y., Edwards, R.L., Ellwood, M., Fahrbach, E., Fitzsimmons, J.N., Flegal, A.R., Fleisher, M.Q., van de Flierdt, T., Frank, M., Friedrich, J., Fripiat, F., Frollje, H., Galer, S.J.G., Gamo, T., Ganeshram, R.S., Garcia-Orellana, J., Garcia-Solsona, E., GaultRingold, M., George, E., Gerringa, L.J.A., Gilbert, M., Godoy, J.M., Goldstein, S.L., Gonzalez, S.R., Grissom, K., Hammerschmidt, C., Hartman, A., Hassler, C.S., Hathorne, E.C., Hatta, M., Hawco, N., Hayes, C.T., Heimburger, L.E., Helgoe, J., Heller, M., Henderson, G.M., Henderson, P.B., van Heuven, S., Ho, P., Horner, T.J., Hsieh, Y.T., Huang, K.F., Humphreys, M.P., Isshiki, K., Jacquot, J.E., Janssen, D.J., Jenkins, W.J., John, S., Jones, E.M., Jones, J.L., Kadko, D.C., Kayser, R., Kenna, T.C., Khondoker, R., Kim, T., Kipp, L., Klar, J.K., Klunder, M., Kretschmer, S., Kumamoto, Y., Laan, P., Labatut, M., Lacan, F., Lam, P.J., Lambelet, M., Lamborg, C.H., Le Moigne, F.A.C., Le Roy, E., Lechtenfeld, O.J., Lee, J.M., Lherminier, P., Little, S., Lopez-Lora, M., Lu, Y.B., Masque, P., Mawji, E., McClain, C.R., Measures, C., Mehic, S., Menzel Barraqueta, J.L., van der Merwe, P., Middag, R., Mieruch, S., Milne, A., Minami, T., Moffett, J.W., Moncoiffe, G., Moore, W.S., Morris, P.J., Morton, P.L., Nakaguchi, Y., Nakayama, N., Niedermiller, J., Nishioka, J., Nishiuchi, A., Noble, A., Obata, H., Ober, S., Ohnemus, D.C., van Ooijen, J., O'Sullivan, J., Owens, S., Pahnke, K., Paul, M., Pavia, F., Pena, L.D., Petersh, B., Planchon, F., Planquette, H., Pradoux, C., Puigcorbe, V., Quay, P., Queroue, F., Radic, A., Rauschenberg, S., Rehkamper, M., Rember, R., Remenyi, T., Resing, J.A., Rickli, J., Rigaud, S., Rijkenberg, M.J.A., Rintoul, S., Robinson, L.F., Roca-Marti, M., Rodellas, V., Roeske, T., Rolison, J.M., Rosenberg, M., Roshan, S., van der Loaff, M.M.R., Ryabenko, E., Saito, M.A., Salt, L.A., Sanial, V., Sarthou, G., Schallenberg, C., Schauer, U., Scher, H., Schlosser, C., Schnetger, B., Scott, P., Sedwick, P.N., Semiletov, I., Shelley, R., Sherrell, R.M., Shiller, A.M., Sigman, D.M., Singh, S.K., Slagter, H.A., Slater, E., Smethie, W.M., Snaith, H., Sohrin, Y., Sohst, B., Sonke, J.E., Speich, S., Steinfeldt, R., Stewart, G., Stichel, T., Stirling, C.H., Stutsman, J., Swarr, G.J., Swift, J.H., Thomas, A., Thorne, K., Till, C.P., Till, R., Townsend, A.T., Townsend, E., Tuerena, R., Twining, B.S., Vance, D., Velazquez, S., Venchiarutti, C., VillaAlfageme, M., Vivancos, S.M., Voelker, A.H.L., Wake, B., Warner, M.J., Watson, R., van Weerlee, E., Weigand, M.A., Weinstein, Y., Weiss, D., Wisotzki, A., Woodward, E.M.S., Wu, J.F., Wu, Y.Z., Wuttig, K., Wyatt, N., Xiang, Y., Xie, R.F.C., Xue, Z.C., Yoshikawa, H., Zhang, J., Zhang, P., Zhao, Y., Zheng, L.J., Zheng, X.Y., Zieringer, M., Zimmer, L.A., Ziveri, P., Zunino, P., Zurbrick, C., 2018. The GEOTRACES Intermediate Data Product 2017. Chemical Geology 493, 210-223. DOI: 10.1016/j.chemgeo.2018.05.040.

Sclater, F.R., Boyle, E., Edmond, J.M., 1976. On the marine geochemistry of nickel. Earth and Planetary Science Letters 31, 119-128. DOI: http://dx.doi.org/10.1016/0012$\underline{821 X(76) 90103-5 .}$.

Sieber, M., Conway, T.M., de Souza, G.F., Obata, H., Takano, S., Sohrin, Y., Vance, D., 2019. Physical and biogeochemical controls on the distribution of dissolved cadmium and its isotopes in the Southwest Pacific Ocean. Chemical Geology 511, 494-509. DOI: https://doi.org/10.1016/j.chemgeo.2018.07.021.

Sohrin, Y., Urushihara, S., Nakatsuka, S., Kono, T., Higo, E., Minami, T., Norisuye, K., Umetani, S., 2008. Multielemental determination of GEOTRACES key trace metals in seawater by ICPMS after preconcentration using an ethylenediaminetriacetic acid chelating resin. Analytical Chemistry 80, 6267-6273. DOI: 10.1021/ac800500f. 
Takano, S., Tanimizu, M., Hirata, T., Shin, K.C., Fukami, Y., Suzuki, K., Sohrin, Y., 2017. A simple and rapid method for isotopic analysis of nickel, copper, and zinc in seawater using chelating extraction and anion exchange. Analytica Chimica Acta 967, 1-11. DOI: 10.1016/j.aca.2017.03.010.

Takano, S., Tanimizu, M., Hirata, T., Sohrin, Y., 2013. Determination of isotopic composition of dissolved copper in seawater by multi-collector inductively coupled plasma mass spectrometry after pre-concentration using an ethylenediaminetriacetic acid chelating resin. Analytica Chimica Acta 784, 33-41. DOI: 10.1016/j.aca.2013.04.032.

Twining, B.S., Baines, S.B., 2013. The Trace Metal Composition of Marine Phytoplankton, in: Carlson, C.A., Giovannoni, S.J. (Eds.), Annual Review of Marine Science, Vol 5, pp. 191215.

Twining, B.S., Baines, S.B., Fisher, N.S., 2004. Element stoichiometries of individual plankton cells collected during the Southern Ocean Iron Experiment (SOFeX). Limnology and Oceanography 49, 2115-2128. DOI: 10.4319/lo.2004.49.6.2115.

Twining, B.S., Baines, S.B., Vogt, S., Nelson, D.M., 2012. Role of diatoms in nickel biogeochemistry in the ocean. Global Biogeochemical Cycles 26. DOI: $10.1029 / 2011 \mathrm{gb} 004233$.

Vance, D., Little, S.H., Archer, C., Cameron, V., Andersen, M.B., Rijkenberg, M.J.A., Lyons, T.W., 2016. The oceanic budgets of nickel and zinc isotopes: the importance of sulfidic environments as illustrated by the Black Sea. Philos. Trans. R. Soc. Lond. Ser. AMath. Phys. Eng. Sci. 374. DOI: 10.1098/rsta.2015.0294.

Vance, D., Little, Susan H., de Souza, Gregory F., Khatiwala, S., Lohan, Maeve C., Middag, R., 2017. Silicon and zinc biogeochemical cycles coupled through the Southern Ocean. Nat. Geosci. 10, 202. DOI: 10.1038/ngeo2890

https://www.nature.com/articles/ngeo2890\#supplementary-information.

Wang, R.M., Archer, C., Bowie, A.R., Vance, D., 2019. Zinc and nickel isotopes in seawater from the Indian Sector of the Southern Ocean: The impact of natural iron fertilization versus Southern Ocean hydrography and biogeochemistry. Chemical Geology 511, 452-464. DOI: https://doi.org/10.1016/j.chemgeo.2018.09.010.

Wasylenki, L.E., Howe, H.D., Spivak-Birndorf, L.J., Bish, D.L., 2015. Ni isotope fractionation during sorption to ferrihydrite: Implications for $\mathrm{Ni}$ in banded iron formations. Chemical Geology 400, 56-64. DOI: http://dx.doi.org/10.1016/j.chemgeo.2015.02.007.

Wyatt, N.J., Milne, A., Woodward, E.M.S., Rees, A.P., Browning, T.J., Bouman, H.A., Worsfold, P.J., Lohan, M.C., 2014. Biogeochemical cycling of dissolved zinc along the GEOTRACES South Atlantic transect GA10 at 40 S. Global Biogeochemical Cycles 28, 4456. DOI: 10.1002/2013gb004637.

Xie, R.C., Galer, S.J.G., Abouchami, W., Rijkenberg, M.J.A., de Baar, H.J.W., De Jong, J., Andreae, M.O., 2017. Non-Rayleigh control of upper-ocean Cd isotope fractionation in the western South Atlantic. Earth and Planetary Science Letters 471, 94-103. DOI: https://doi.org/10.1016/j.eps1.2017.04.024. 
Xue, Z.C., Rehkamper, M., Horner, T.J., Abouchami, W., Middag, R., van de Flierdt, T., de Baar, H.J.W., 2013. Cadmium isotope variations in the Southern Ocean. Earth and Planetary Science Letters 382, 161-172. DOI: 10.1016/j.epsl.2013.09.014.

Zhao, Y., Vance, D., Abouchami, W., de Baar, H.J.W., 2014. Biogeochemical cycling of zinc and its isotopes in the Southern Ocean. Geochimica Et Cosmochimica Acta 125, 653-672. DOI: 10.1016/j.gca.2013.07.045. 
Table 1. Macronutrient and dissolved $\mathrm{Ni}$ and $\delta^{60} \mathrm{Ni}$ for the six superstations along the GA10 transect.

\begin{tabular}{lccccccc}
\hline $\begin{array}{l}\text { Sample } \\
\text { ID }\end{array}$ & $\begin{array}{c}\text { Depth } \\
(\mathrm{m})\end{array}$ & $\begin{array}{c}\delta^{60} \mathrm{Ni} \\
(\% \mathrm{o})\end{array}$ & $2 \sigma^{\mathrm{a}}$ & $\mathrm{Ni}(\mathrm{nM})$ & $\begin{array}{c}\mathrm{NO}_{3}^{-\mathrm{b}} \\
(\mu \mathrm{mol} / \mathrm{kg})\end{array}$ & $\begin{array}{c}\mathrm{PO}_{4}^{3-\mathrm{b}} \\
(\mu \mathrm{mol} / \mathrm{kg})\end{array}$ & $\begin{array}{c}\mathrm{SiO}_{4}^{4-\mathrm{b}} \\
(\mu \mathrm{mol} / \mathrm{kg})\end{array}$ \\
\hline
\end{tabular}

Cruise D357: $18^{\text {th }}$ Oct $-22^{\text {nd }}$ Nov 2010, R.R.S. Discovery

D357 Station 3, -36.45559 N, 13.38788 E, Bottom depth $4911 \mathrm{~m}$

$\begin{array}{lcllllll}\text { FISH-3 } & 1 & 1.48 & 0.03 & 2.88 & 5.02 & 0.53 & 1.93 \\ 00183 & 25 & 1.40 & 0.03 & 3.24 & 5.19 & 0.52 & 1.99 \\ 00180 & 49 & 1.47 & 0.04 & 3.09 & 5.32 & 0.53 & 1.97 \\ 00177 & 99 & 1.46 & 0.04 & 3.26 & 7.33 & 0.67 & 2.53 \\ 00174 & 198 & 1.42 & 0.04 & 3.47 & 11.49 & 0.88 & 4.11 \\ 00171 & 397 & 1.36 & 0.04 & 4.44 & 20.99 & 1.44 & 10.40 \\ 0170 & 594 & 1.32 & 0.03 & 5.27 & 27.60 & 1.88 & 18.61 \\ 00169 & 989 & 1.38 & 0.04 & 6.25 & 33.05 & 2.36 & 49.74 \\ 0167 & 1975 & 1.40 & 0.03 & 7.69 & 27.29 & 1.99 & 55.92 \\ 0166 & 2955 & 1.20 & 0.07 & 5.70 & 25.49 & 1.88 & 58.61 \\ 0164 & 3931 & 1.32 & 0.04 & 7.07 & 30.08 & 2.31 & 98.36 \\ 00163 & 4724 & 1.25 & 0.06 & 6.72 & 31.19 & 2.42 & 106.90\end{array}$

D357 Station 6, -39.98831 N, 0.91628 E, Bottom depth $4953 m$

$\begin{array}{lccccccc}\text { FISH-6 } & 2 & 1.43 & 0.03 & 3.55 & 7.30 & 0.73 & 1.76 \\ 0448 & 25 & 1.42 & 0.04 & 3.44 & 7.58 & 0.68 & 1.85 \\ 0445 & 49 & 1.40 & 0.04 & 3.43 & 7.71 & 0.69 & 1.84 \\ 0442 & 100 & 1.49 & 0.05 & 3.54 & 8.38 & 0.74 & 1.85 \\ 0439 & 200 & 1.39 & 0.04 & 3.88 & 14.75 & 1.06 & 3.90 \\ 00436 & 401 & 1.32 & 0.04 & 4.79 & 24.77 & 1.67 & 10.46 \\ 0435 & 600 & 1.24 & 0.03 & 5.41 & 28.48 & 1.93 & 18.06 \\ 0434 & 998 & 1.27 & 0.03 & 6.25 & 33.22 & 2.29 & 44.52 \\ 0432 & 1999 & 1.28 & 0.03 & 6.04 & 28.78 & 2.01 & 62.35 \\ 0431 & 2998 & 1.20 & 0.05 & 6.85 & 26.64 & 1.87 & 66.17 \\ 0429 & 4000 & 1.26 & 0.04 & 7.29 & 30.41 & 2.19 & 101.34 \\ 0428 & 4501 & 1.33 & 0.05 & 6.73 & 31.13 & 2.26 & 108.40\end{array}$

D357 Station 11, -39.29276 N, 7.65178 E, Bottom depth 5300m

$\begin{array}{lcllllll}\text { FISH-11 } & 1 & 1.55 & 0.03 & 2.71 & 2.21 & 0.38 & 1.60 \\ 0785 & 25 & 1.50 & 0.04 & 2.63 & 2.05 & 0.34 & 1.60 \\ 0782 & 49 & 1.51 & 0.05 & 2.62 & 2.09 & 0.34 & 1.52 \\ 0779 & 99 & 1.46 & 0.13 & 2.86 & 3.64 & 0.45 & 1.97 \\ 0776 & 199 & 1.37 & 0.04 & 3.31 & 10.18 & 0.80 & 3.05 \\ 0773 & 401 & 1.37 & 0.03 & 4.12 & 18.52 & 1.29 & 7.03 \\ 0772 & 700 & 1.30 & 0.03 & 5.37 & 28.31 & 1.94 & 18.25 \\ 0771 & 1000 & 1.30 & 0.03 & 6.17 & 32.22 & 2.27 & 40.24 \\ 0769 & 1999 & 1.31 & 0.05 & 5.88 & 28.24 & 2.02 & 57.83 \\ 0768 & 2999 & 1.30 & 0.04 & 6.23 & 25.65 & 1.85 & 59.23 \\ 0767 & 4000 & 1.35 & 0.08 & 6.82 & 29.24 & 2.18 & 92.17 \\ 0767 & 4000 & 1.28 & 0.06 & 6.44 & 29.24 & 2.18 & 92.17 \\ 0766 & 5000 & 1.27 & 0.05 & 7.37 & 30.93 & 2.33 & 106.69 \\ 0764 & 5260 & 1.26 & 0.06 & 6.80 & 31.10 & 2.34 & 107.06\end{array}$


Cruise JC068: $24^{\text {th }}$ Dec. $2010-27^{\text {th }}$ Jan. 2011, R.R.S. James Cook

\begin{tabular}{|c|c|c|c|c|c|c|c|}
\hline \multicolumn{8}{|c|}{ JC068 Station 12, -40.00222 N, -16.46338 E, Bottom depth $3093 m$} \\
\hline 1062 & 4 & 1.61 & 0.03 & 2.41 & 0.17 & 0.20 & 0.66 \\
\hline 1560 & 16 & 1.59 & 0.05 & 2.30 & 0.47 & 0.21 & 0.75 \\
\hline 1555 & 42 & 1.67 & 0.03 & 2.39 & 0.64 & 0.22 & 0.63 \\
\hline 1551 & 95 & 1.56 & 0.03 & 3.00 & 6.60 & 0.55 & 2.34 \\
\hline 1547 & 193 & 1.53 & 0.03 & 3.08 & 7.13 & 0.60 & 2.38 \\
\hline 1517 & 492 & 1.42 & 0.09 & 4.45 & 19.73 & 1.33 & 6.89 \\
\hline 1513 & 990 & 1.32 & 0.08 & 6.26 & 29.92 & 2.08 & 29.75 \\
\hline 1509 & 1488 & 1.35 & 0.06 & 6.48 & 31.36 & 2.34 & 55.61 \\
\hline 1505 & 1987 & 1.33 & 0.04 & 6.10 & 27.15 & 2.08 & 57.37 \\
\hline 1502 & 2487 & 1.30 & 0.06 & 5.66 & 24.75 & 1.91 & 56.69 \\
\hline 1498 & 2988 & 1.26 & 0.08 & 6.07 & 24.44 & 1.91 & 63.83 \\
\hline
\end{tabular}

JC068 Station 18, -40.00 N, -42.41671 E, Bottom depth $5156 \mathrm{~m}$

$\begin{array}{cccccccc}1093 & 5 & 1.49 & 0.03 & 3.14 & 0.05 & 0.19 & 0.28 \\ 2019 & 45 & 1.31 & 0.09 & 3.66 & 6.21 & 0.56 & 1.81 \\ 2013 & 96 & 1.33 & 0.09 & 4.03 & 13.17 & 0.85 & 3.38 \\ 2010 & 196 & 1.34 & 0.07 & 4.66 & 21.66 & 1.37 & 6.41 \\ 2007 & 494 & 1.36 & 0.06 & 5.46 & 27.15 & 1.75 & 14.76 \\ 2004 & 742 & 1.35 & 0.05 & 5.85 & 30.98 & 2.06 & 29.36 \\ 2002 & 992 & 1.34 & 0.05 & 6.37 & 33.69 & 2.28 & 49.06 \\ 1972 & 1990 & 1.32 & 0.05 & 5.65 & 26.20 & 1.93 & 54.67 \\ 1969 & 2488 & 1.37 & 0.04 & 5.55 & 25.12 & 1.84 & 57.18 \\ 1962 & 3983 & 1.33 & 0.04 & 6.91 & 29.49 & 2.42 & 115.45 \\ 1952 & 5102 & 1.29 & 0.08 & 7.46 & 31.27 & 2.51 & 127.01\end{array}$

JC068 Station 21, -37.00922 N, -52.49924 E, Bottom depth $3321 \mathrm{~m}$

\begin{tabular}{lccccccc}
1104 & 5 & 1.44 & 0.04 & 3.01 & 0.05 & 0.18 & 1.42 \\
2328 & 56 & 1.64 & 0.04 & 2.26 & 0.01 & 0.02 & 1.05 \\
2322 & 88 & 1.74 & 0.08 & 2.32 & 0.46 & 0.10 & 1.00 \\
2316 & 196 & 1.61 & 0.06 & 2.59 & 3.91 & 0.33 & 1.90 \\
2313 & 296 & 1.51 & 0.08 & 2.87 & 6.87 & 0.51 & 2.50 \\
2311 & 510 & 1.50 & 0.09 & 3.97 & 17.62 & 1.15 & 6.56 \\
2282 & 992 & 1.27 & 0.08 & 6.02 & 18.87 & 1.28 & 27.56 \\
2279 & 1492 & 1.37 & 0.05 & 6.52 & 34.47 & 2.41 & 57.88 \\
2275 & 1993 & 1.27 & 0.10 & 5.74 & 27.14 & 1.85 & 39.07 \\
2268 & 2987 & 1.21 & 0.06 & 6.99 & 30.70 & 2.24 & 94.82 \\
\hline
\end{tabular}

${ }^{\mathrm{a}}$ Internal analytical error, with all measurement uncertainties propagated through the double spike reduction calculation. The long-term reproducibility of secondary standards is $\pm 0.07 \%$ (2SD) for $\delta^{60} \mathrm{Ni}$, larger value is shown in figures.

b (Schlitzer et al., 2018) 


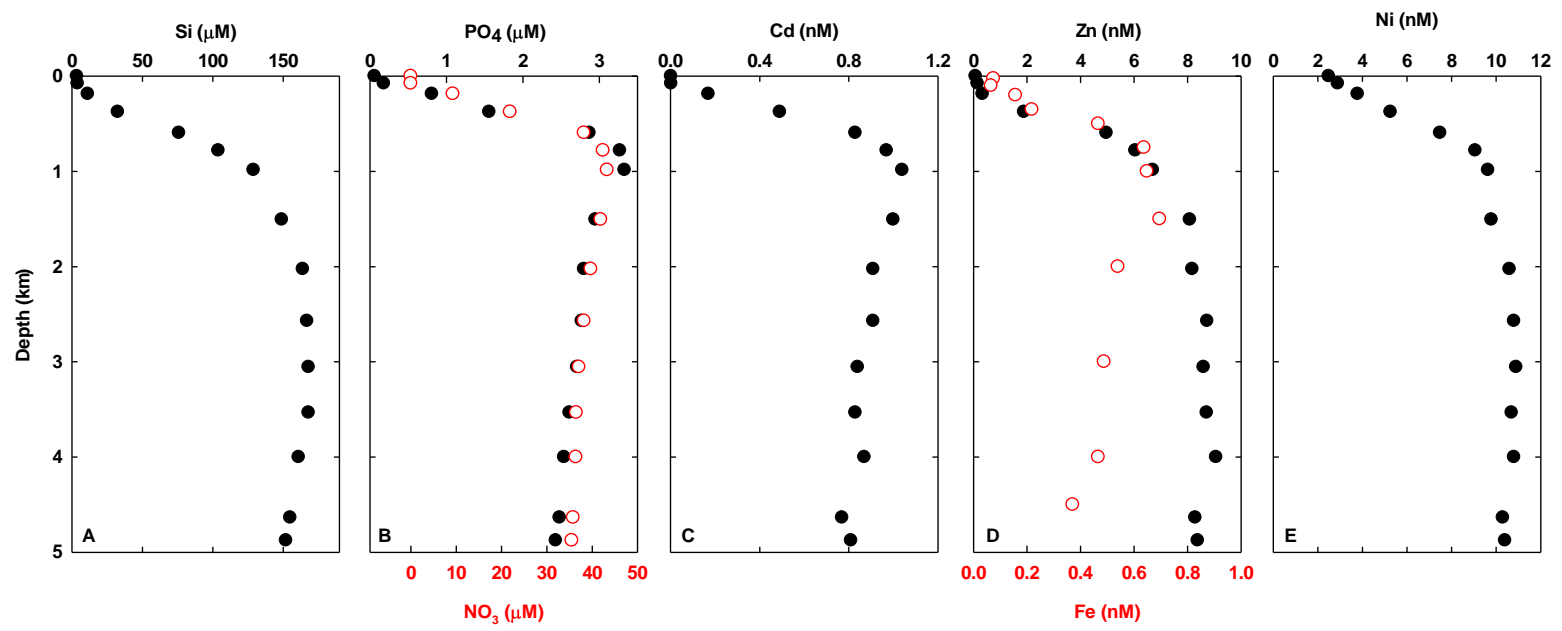

Figure 1. Depth profiles of dissolved Ni concentrations in the North Pacific compared to the major nutrients, as well as other trace metal micronutrients. All data except for Fe are for Station H77 in Bruland et al. (1980). Iron data are for the nearby SAFe station, and are reported in Conway and John (2015). 


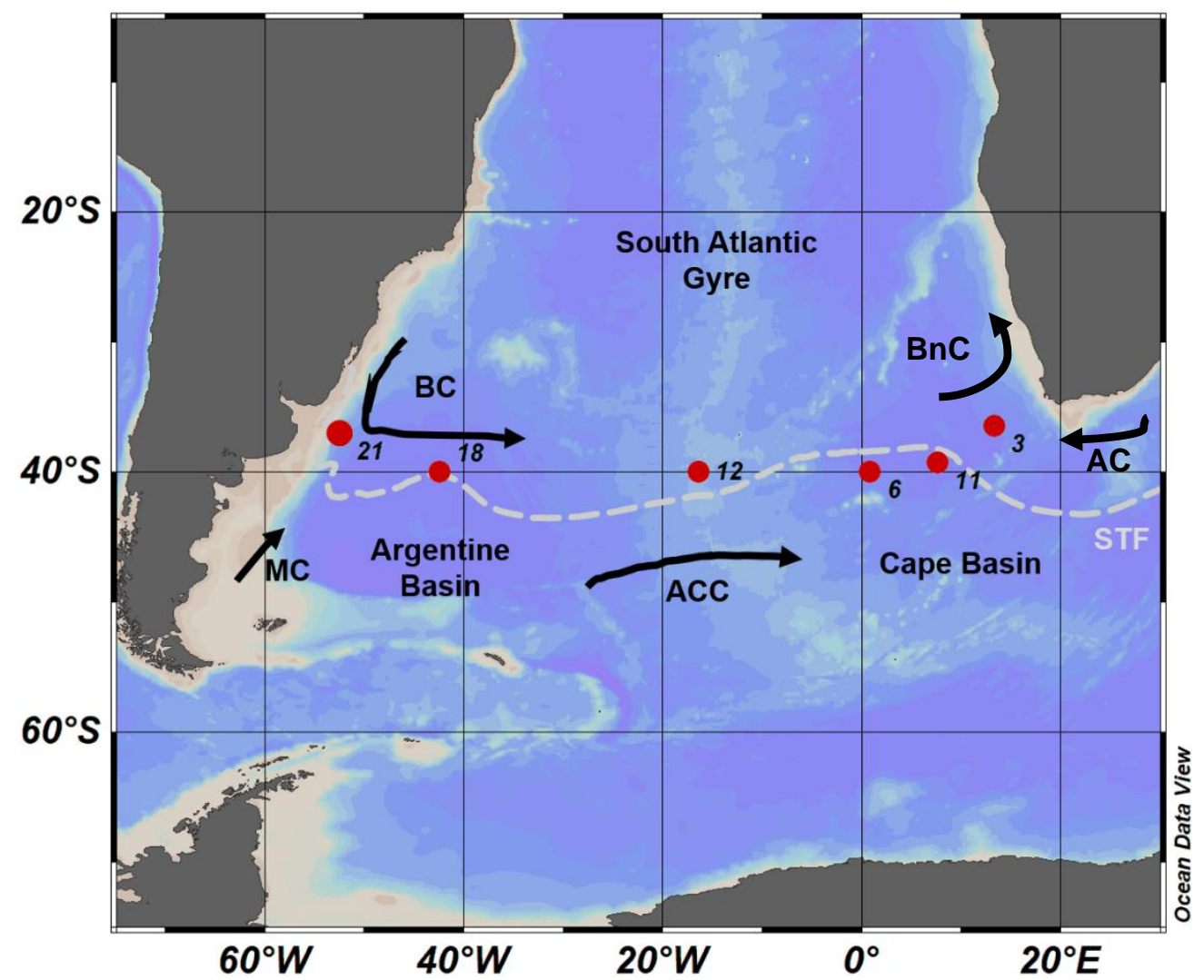

Figure 2. Map of UK GEOTRACES South Atlantic GA10 section showing superstations for which Ni data are reported here, as well as relevant ocean currents and fronts. $(\mathrm{AC}=$ Agulhas Current, $\mathrm{ACC}=\mathrm{Antarctic}$ Circumpolar Current, $\mathrm{BC}=$ Brasil Current, $\mathrm{BnC}=$ Benguela Current, $\mathrm{MC}=$ Malvinas Current, $\mathrm{STF}=$ Subtropical Front.) Superstations 4, 6 and 11 in the Cape Basin were occupied during cruise leg D357 (Oct-Nov 2010). Superstations 12, 18 and 21 were occupied during cruise leg JC068 in the Argentine Basin (Dec 2011Jan 2012). 

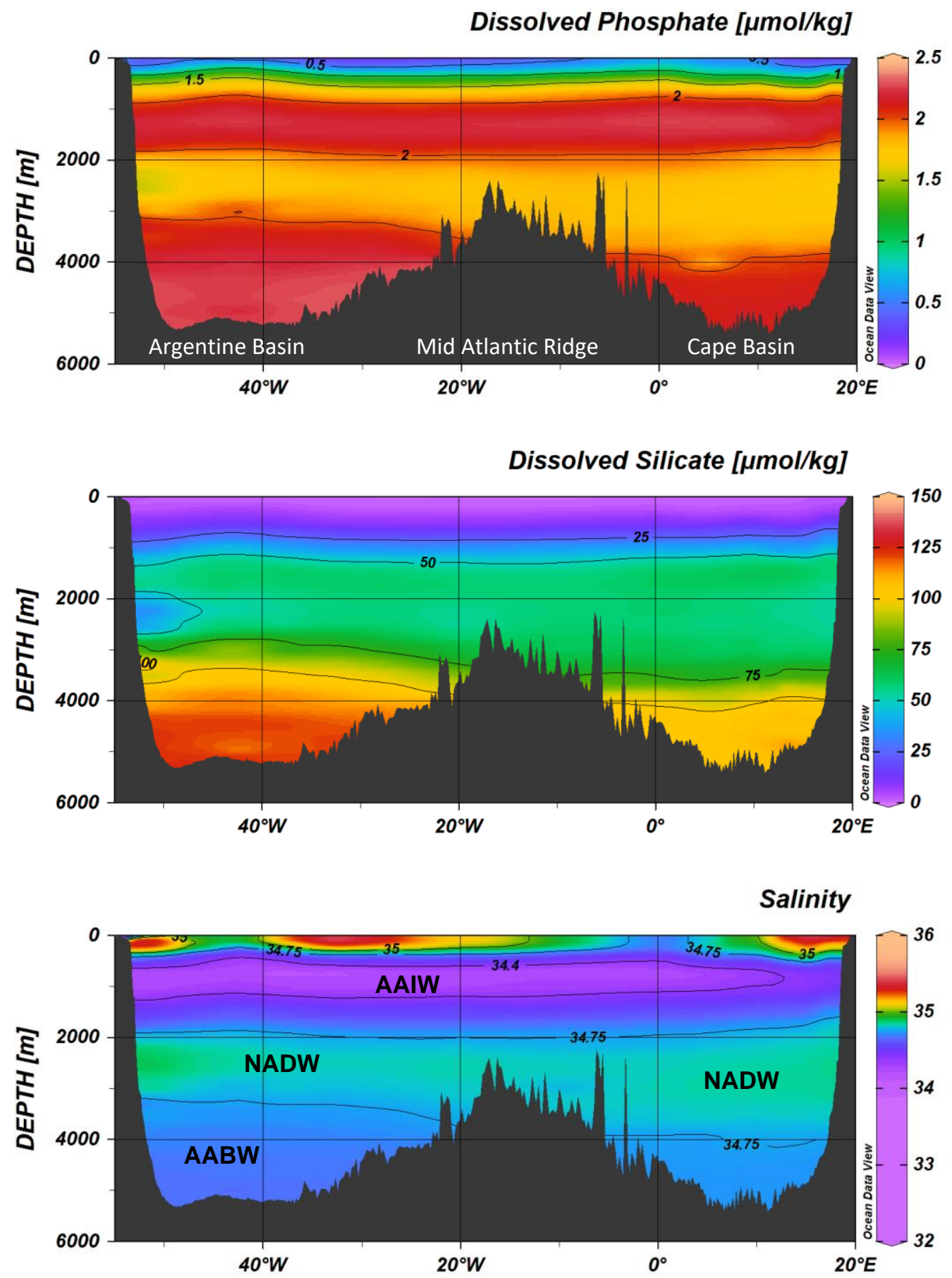

Figure 3. Macronutrients (top) phosphate and (middle) silicate and (bottom) salinity, indicating the major water masses, along the GA10 $40^{\circ} \mathrm{S}$ section. $(\mathrm{AABW}=$ Antarctic Bottom Water, AAIW = Antarctic Intermediate Water, NADW = North Atlantic Deep Water) Data from Geotraces Intermediate Data Product (Schlitzer et al., 2018). 

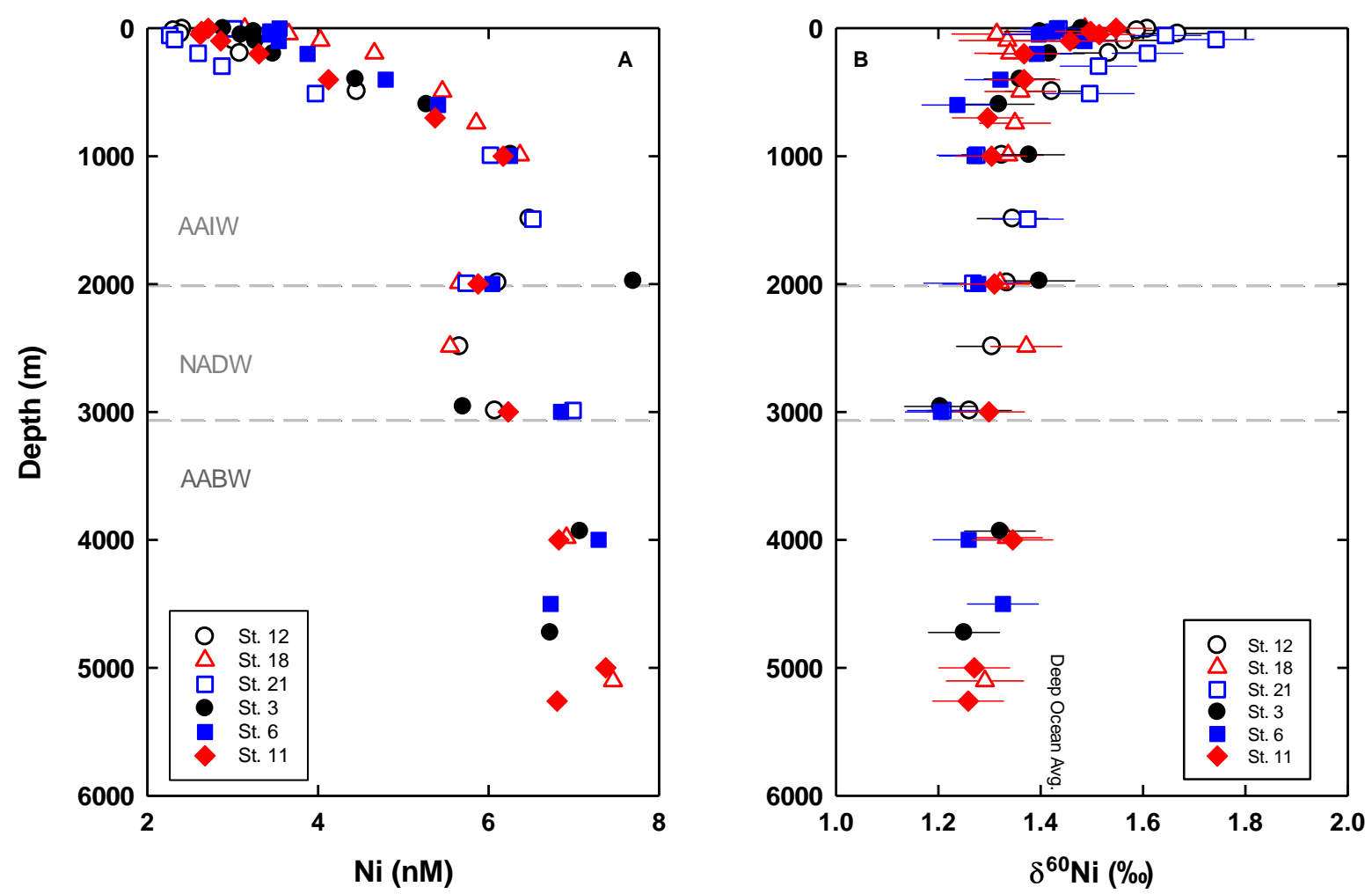

Figure 4. Depth profiles of dissolved $\mathrm{Ni}$ and $\mathrm{Ni}$ isotopes $\left(\delta^{60} \mathrm{Ni}\right)$ at the six superstations along the GEOTRACES GA10 transect at $40^{\circ} \mathrm{S}$ in the Atlantic Ocean. Filled symbols show data from the Cape Basin (Cruise Leg D357) and open symbols show data from the Argentine Basin (Leg JC068). Dashed lines delineate the approximate boundaries of the major water masses (Wyatt et al., 2014). The grey bar indicates the deep ocean average $\mathrm{Ni}$ isotope composition, at $\delta^{60} \mathrm{Ni}=+1.31 \pm 0.12 \%$. (For interpretation of the references to colour in this figure legend, the reader is referred to the web version of this article.) 


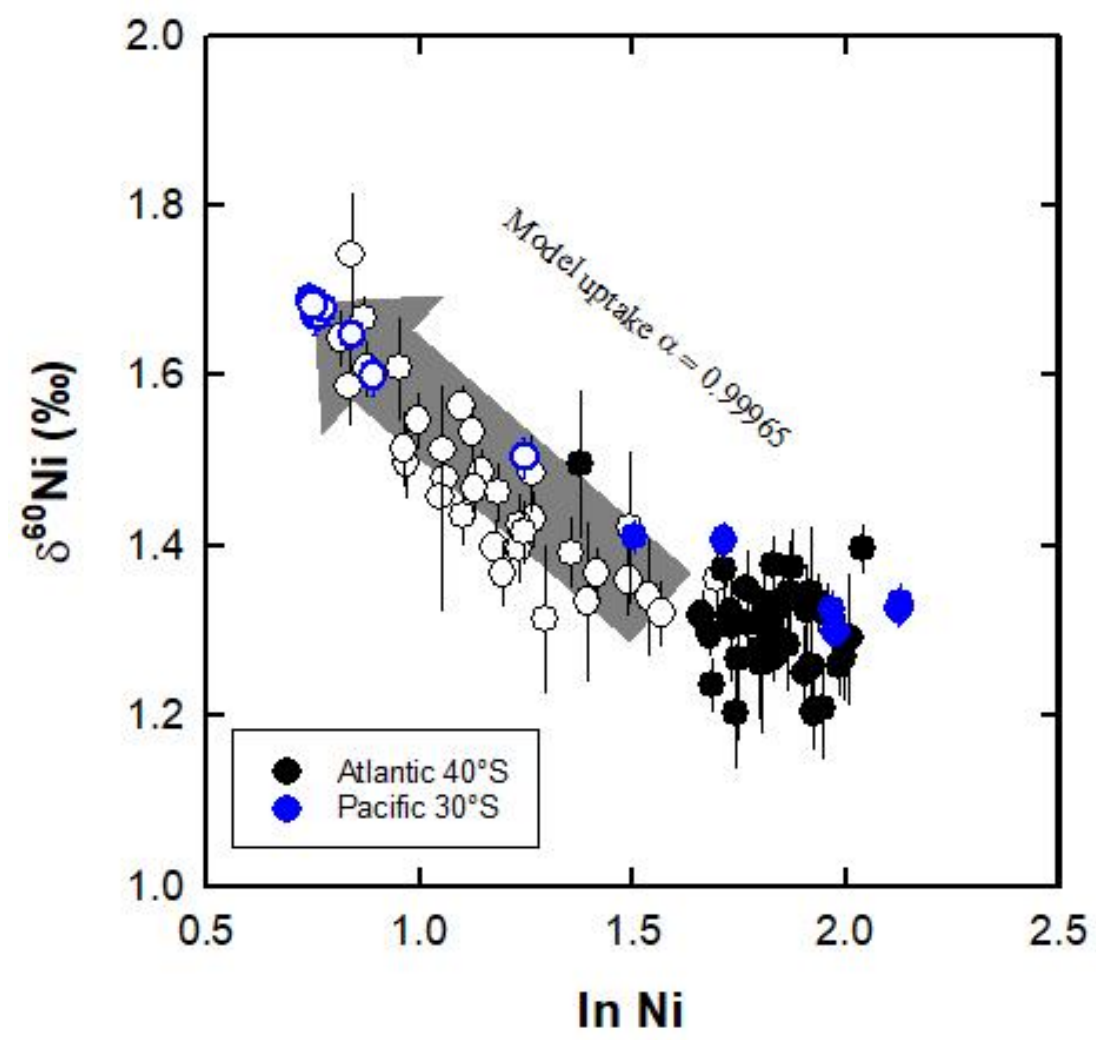

Figure 5: All data for Ni concentrations and isotopes presented here for the South Atlantic and for the South Pacific (Station KH 14-6, 30 ${ }^{\circ} \mathrm{S}, 170^{\circ} \mathrm{W}$ ) from Takano et al. (2017). Filled symbols show data from depths beneath $500 \mathrm{~m}$ while open symbols show depths above this. The grey arrow shows a modelled Rayleigh-type evolution of the residual dissolved phase $\left(\delta^{60} \mathrm{Ni}_{\text {res }}\right)$ as $\mathrm{Ni}$ is removed from a starting pool via a generalised uptake mechanism. In this example $\delta^{60} \mathrm{Ni}_{\text {res }}$ is approximately $\delta^{60} \mathrm{Ni}_{\text {initial }}{ }^{\alpha-1}$, where $\mathrm{f}$ is the fraction of the starting pool remaining. The calculation shown here assumes that the entire pool of dissolved Ni is available for removal from solution (see Fig. 7), and the calculated fractionation factor $(\alpha)$ obtained represents the maximum fractionation for removal of $\mathrm{Ni}$. 

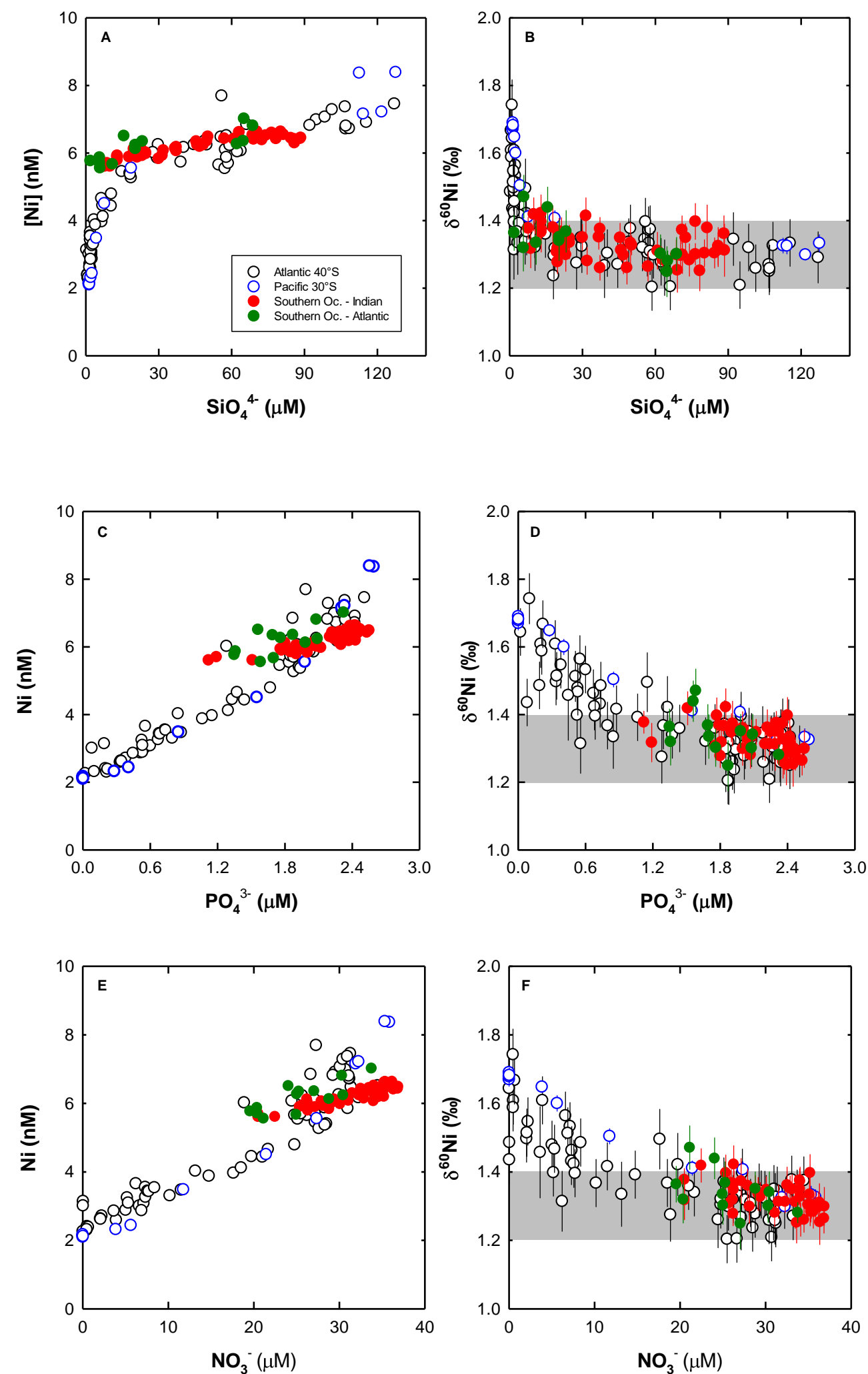

Figure 6. Relationships between dissolved $\mathrm{Ni}$, Ni isotopes $\left(\delta^{60} \mathrm{Ni}\right)$ and the macronutrients for stations north of the Polar Front (open symbols) studied here (black) and for the South Pacific (blue; Takano et al., 2017). These data are compared with those for two locations at or south of the Polar Front (filled symbols). Red symbols show data from the Indian Sector of the Southern Ocean (Wang et al., 2019) and green the Atlantic sector (Cameron and Vance, 2014). (For interpretation of the references to colour in this figure legend, the reader is referred to the web version of this article.) 


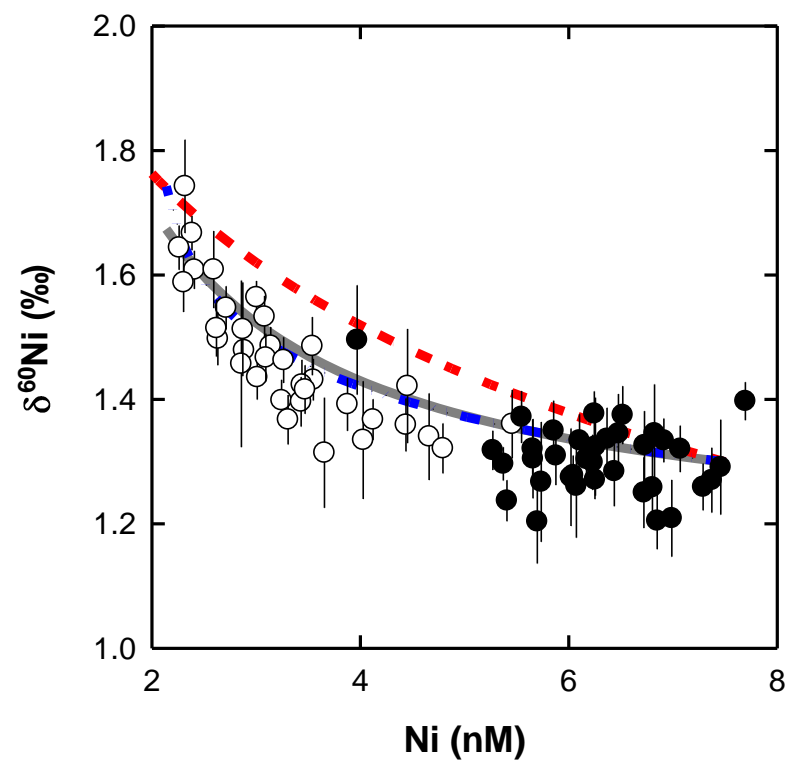

Figure 7. Ni isotope data for the South Atlantic plotted against Ni concentration. Filled symbols show data below $500 \mathrm{~m}$ and open circles show data above. The dashed red line shows the same Rayleigh model as in Fig. 5 , assuming that all of the $\mathrm{Ni}$ is available for uptake, but with a starting $\mathrm{Ni}$ pool that represents the measured deep ocean concentrations. The dashed blue line also models Ni removal via a Rayleigh-type process, but in this case assumes an unavailable pool of $\mathrm{Ni}$, and that no bio-available $\mathrm{Ni}$ remains in the lowest concentration sample. The solid grey line shows the result of a model involving; (a) two distinct pools of Ni, one bio-available and one not because it is complexed to organic ligands; (b) a ligand-bound pool with a $\delta^{60} \mathrm{Ni}=1.7 \%$ and, by mass balance, a bioavailable pool with a $\delta^{60} \mathrm{Ni}=1.2 \%$; (c) uptake of the bio-available pool only, without any isotope fractionation during uptake. 